\title{
Economic evaluations of angiotensin-converting enzyme inhibitors and angiotensin II receptor blockers in type 2 diabetic nephropathy: a systematic review
}

Yunyu Huang ${ }^{1,2,3^{*}}$, Qiyun Zhou' ${ }^{1}$ Flora M Haaijer-Ruskamp ${ }^{2}$ and Maarten J Postma'

\begin{abstract}
Background: Structured comparison of pharmacoeconomic analyses for ACEls and ARBs in patients with type 2 diabetic nephropathy is still lacking. This review aims to systematically review the cost-effectiveness of both ACEls and ARBs in type 2 diabetic patients with nephropathy.

Methods: A systematic literature search was performed in MEDLINE and EMBASE for the period from November 1 , 1999 to Oct 31, 2011. Two reviewers independently assessed the quality of the articles included and extracted data. All cost-effectiveness results were converted to 2011 Euros.

Results: Up to October 2011, 434 articles were identified. After full-text checking and quality assessment, 30 articles were finally included in this review involving 39 study settings. All 6 ACEls studies were literature-based evaluations which synthesized data from different sources. Other 33 studies were directed at ARBs and were designed based on specific trials. The Markov model was the most common decision analytic method used in the evaluations. From the cost-effectiveness results, 37 out of 39 studies indicated either ACEls or ARBs were cost-saving comparing with placebo/conventional treatment, such as amlodipine. A lack of evidence was assessed for valid direct comparison of cost-effectiveness between ACEls and ARBs.
\end{abstract}

Conclusion: There is a lack of direct comparisons of ACEls and ARBs in existing economic evaluations. Considering the current evidence, both ACEls and ARBs are likely cost-saving comparing with conventional therapy, excluding such RAAS inhibitors.

\section{Background}

Approximately one fourth to one third of patients with diabetes mellitus develop renal manifestations [1-4]. Clinical stages of diabetic nephropathy are generally categorized into stages based on the values of urinary albumin excretion: microalbuminuria (MiA) and macroalbuminuria (MaA) [5]. The prevalence of $\mathrm{MiA}$ and $\mathrm{MaA}$ in type 2 diabetes is as high as $37-40 \%$ in western countries and 57.4-59.8\% in Asian countries [6-8]. 20-40\% of type 2 diabetic patients with MiA progress to overt nephropathy,

\footnotetext{
*Correspondence: y.huang02@umcg.nl

'Department of Pharmacy, Unit of Pharmaco Epidemiology \& Pharmaco Economics, University of Groningen, Groningen, The Netherlands

2Department of Clinical Pharmacology, University Medical Center Groningen, University of Groningen, Groningen, The Netherlands

Full list of author information is available at the end of the article
}

and by 20 years after onset of overt nephropathy, about $20 \%$ will have progressed to end-stage renal diseases (ESRD) [9]. Because of the large prevalence, diabetes has become the most common single cause of ESRD in the U.S. and Europe [10,11]. As therapies and interventions for coronary artery disease continue to improve, more patients with type 2 diabetes may be expected to survive long enough to develop renal failure.

In developed countries, ESRD is a major cost driver for health-care systems, with annual growth of dialysis programs ranging between $6 \%$ and $12 \%$ over the past two decades and continuing to grow, particularly in developing countries [12]. Although there are no definitive cure solutions, there is good evidence that adequate treatment can delay or prevent the progress of diabetic nephropathy including strict control of glycaemia, early

\section{Biomed Central}


treatment of hypertension, dietary protein restriction and lipid-lowering therapy [13]. Targeting renin-angiotensin-aldosterone system (RAAS) is the most effective way to delay renal disease progression. Treatment guidelines therefore recommended angiotensin-converting enzyme inhibitors (ACEIs) and angiotensin II receptor blockers (ARBs) as the first-choice agents for treating nephropathy in diabetic patients [14].

Both ACEIs and ARBs target the RAAS and have proven their renal protective effects in diabetic patients in various clinical trials. One disadvantage of ACEIs [15-17] in comparison with ARBs is the higher risk of dry cough while significant differences in effectiveness between these two drug classes have not been shown convincingly although ARBs have been more thoroughly investigated in controlled settings in the recent decade providing relatively high levels of evidence. Often clinical practice guidelines recommend both ACEIs and ARBs in diabetic patients with or even without (micro)albuminuria [18].

Pharmacoeconomic evaluations of ACEIs and ARBs have been widely applied based on clinical trials' results. The pharmacoeconomic results of ARBs have been reviewed previously [19-26]. ARBs were suggested to be cost saving in type 2 diabetic patients with nephropathy versus conventional therapy, largely due to the high costs of treatment of ESRD. However, a systematic review of cost- effectiveness results of ACEIs in type 2 diabetic patients with renal disease is still lacking. In addition, the need of a structured pharmacoeconomic comparison of the ACEIs with ARBs is pointed out by some researchers [21,26].

The aim of this study is to address the similarities and differences in cost-effectiveness analyses for both ACEIs and ARBs in type 2 diabetic patients with nephropathy. In particular, three objectives are addressed: 1) to summarize the cost-effectiveness of ACEIs; 2) to update the costeffectiveness of ARBs; 3) to compare the characteristics of different economic evaluations and analyze potential differences and similarities in the cost-effectiveness between the two drug classes reviewed.

\section{Methods}

\section{Literature search strategy}

A systematic literature search was performed in MEDLINE and EMBASE for the period November 1, 1999 to Oct 31, 2011. The key words (MeSH headings in MEDLINE, EMtree terms in EMBASE and other text terms) included were (Table 1):

- Indicating target drugs, the variations in and abbreviations of ACEIs and ARBs were searched, such as 'angiotensin receptor antagonists', 'renin angiotensin aldosterone system inhibitors', and

Table 1 Search terms for systematic review

\begin{tabular}{ll}
\hline Search terms & MEDLINE \\
\hline Drug & Mesh: Angiotensin-Converting Enzyme Inhibitors; \\
& Angiotensin Receptor Antagonists; \\
& TIAB (Title and Abstract): ACEls; ARBs; ACEl; ARB; renin \\
& angiotensin system inhibitor*a; renin angiotensin \\
& aldosterone system inhibitor*; ACE inhibitor*; RAS \\
& inhibitor*; RAAS inhibitor*; angiotensin converting \\
& enzyme inhibitor*; renin angiotensin system inhibitor*; \\
& angiotensin receptor blocker*; Losartan; Candesartan; \\
& Valsartan; Irbesartan; Telmisartan; Eprosartan; Olmesartan; \\
& Azilsartan; Benazepril; Captopril; Enalapril; Fosinopril; \\
& Lisinopril; Moexipril; Perindopril; Quinapril; Ramipril; \\
& Trandolapril
\end{tabular}

Diabetic Nephropathy (DN)

Mesh: Diabetes Mellitus, Type 2; Diabetic Nephropathies; Kidney Failure, Chronic;

TIAB: diabetic nephropathy*; diabetic renal disease* diabetic kidney disease*;

Economic Evaluation (EE)

Mesh: Economics, Pharmaceutical; Costs and Cost Analysis; Drug Costs; Cost Savings; Cost of Illness; Cost-Benefit Analysis; TIAB: cost effect*; cost utility; cost benefit*; economic evaluation*; cost analys*

Search Strategy
("Drug Term 1"[Mesh] OR "Drug Term 2"[TIAB] ...) AND ("DN Term 1"[Mesh] OR "DN Term 2"[TIAB] ...) AND ("EE Term 1"[Mesh] OR "EE Term 2"[TIAB] ...)
EMBASE

EMtree: dipeptidyl carboxypeptidase inhibito; angiotensin receptor antagonist;

ab,ti (Abstract and Title): angiotensin receptor blocker; angiotensin receptor blockers; arb; arbs; ace inhibitor; ace inhibitors; angiotensin converting enzyme inhibitor; angiotensin converting enzyme inhibitors; angiotensin converting enzyme (ace) inhibitor; angiotensin converting enzyme (ace) inhibitors; acei; aceis; renin angiotensin system inhibitor; renin angiotensin system inhibitors; renin angiotensin system (ras) inhibitor; renin angiotensin system (ras) inhibitors; ras inhibitor; ras inhibitors; renin angiotensin aldosterone system inhibitor; renin angiotensin aldosterone system inhibitors; raas inhibitor; raas inhibitors; losartan; candesartan; valsartan; irbesartan; telmisartan; eprosartan; olmesartan; azilsartan; benazepril; captopril; enalapril; fosinopril; lisinopril; moexipril; perindopril; quinapril; ramipril; trandolapril;

EMtree: non insulin dependent diabetes mellitus; diabetic nephropathy;

ab,ti: diabetic nephropathy; diabetic nephropathies; diabetic renal diseases; diabetic renal disease; diabetic kidney diseases; diabetic kidney disease

EMtree: pharmacoeconomics; economic evaluation; drug cost; cost control; cost of illness; cost benefit analysis; cost effectiveness analysis;

ab,ti: cost effectiveness; cost utility; cost benefit; economic evaluation; economic evaluations; cost analys;

('Drug Term 1'/exp OR 'Drug Term 2':ab,ti ...) AND

('DN Term 1'/exp OR 'DN Term 2'ab,ti ...) AND ('EE Term 1'/exp OR 'EE Term 2':ab,ti ...) NOT [medline]/lim ${ }^{\mathbf{b}}$ 
specific drug names of different ACEIs or ARBs, including 10 specific ACEIs (such as captopril, enalapril, etc.) and 8 ARBs (such as losartan, irbesartan, etc.).

- Indicating diabetic nephropathy, key words were limited to 'type 2 diabetes' and its variations. Variations of nephropathy were combined with diabetes, such as 'diabetic renal diseases' or 'diabetic kidney diseases'.

- Indicating economic evaluations, various key words relating to different evaluation types,

pharmacoeconomics, cost of drugs and cost analysis were searched, including 'cost-effectiveness analysis' (CEA), 'cost-utility analysis' (CUA), 'cost-benefit analysis' (CBA), and 'cost savings', etc.

The references of identified articles were manually screened for relevant economic evaluations not identified in the above-mentioned searches (snowballing).

\section{Study selection}

Inclusion criteria for the review were as follows (following the PICOS-design):

- Population: patients in studies had to have type 2 diabetes with symptoms of renal diseases;

- Interventions and Comparators: studies must examine an ACEI- or ARB-based treatment regimen for the progression of diabetic nephropathy compared with regimens that did not include these medications, or if available, compare ACEIs with ARBs directly;

- Outcomes: clinical outcomes should be relevant to renal disease symptoms, including overt diabetic nephropathy, ESRD (kidney transplantation or dialysis), all-cause mortality, etc.; and

- Study design: studies had to be original economic evaluations.

Other criteria concerned that studies had to have been published as full-length articles and were peer-reviewed for English-language journals.

Study selection was performed in three rounds. First, tithes and abstracts of searched articles were scanned and checked. In the second round, the full-texts of included articles were read carefully and quality was assessed in the last round. Two authors independently assessed the quality of the articles included and extracted the data. Differences were resolved by consensus.

\section{Quality assessment}

Quality assessment was conducted at the 'study' level, i.e. each study was analyzed one by one. A checklist for critical appraisal of economic evaluations [27] was used to evaluate the study quality. The checklist comprises 12 criteria assessing the study design, outcomes and costs and the extrapolation of the results of an economic evaluation. An additional file shows this checklist in more detail (see Additional file 1).

The criterion 'applicable to local population' was not included in the assessment as we didn't felt this was relevant for the current study; i.e. 11 criteria were considered in the end. In case studies showing cost savings, the absence of an explicit incremental cost-effectiveness ratio (ICER) was classified as adequate, since in that case no incremental ratio is necessary or meaningful.

Studies were subsequently included in the full review if: 1) the outcomes and costs have been assessed as being credibly, 2) at least 6 of the 11 quality criteria were rated as adequate or good; and 3) not more than three quality criteria were assessed as being inadequate.

\section{Data extraction}

Data extraction was based on the 11 criteria included in the quality assessment checklist which concerned: 1) basic information of study design; 2) data on outcomes and costs; and 3) results and conclusions. We grouped articles into two groups, reflecting ACEIs and ARBs. The latter group was subdivided into three subgroups in line with the three mostly analyzed ARBs, irbesartan, losartan and valsartan.

To make the results comparable across the studies, cost-saving or ICER results were standardized to 2011 price levels, by applying the appropriate annual deflators for each country, based on the statistics from the World Bank [28]. Since the deflator data for Taiwan was not available from the World Bank, cost data of this region was not standardized. The original cost-saving result was showed as reference.

All the currencies were converted to 2011 Euros, based on the Euro rate as of June 30th, 2011 [29].

The results of selected studies were classified in 5 categories: 1) cost-saving: net life years or QALYs gained in conjunction with $\geq € 1,000$ saved per patient as compared with the comparison intervention; 2) almost cost-neutral: net life years or QALYs gained, with $<€ 1,000$ saved per patient; 3) very cost-effective: $0<$ ICER $\leq € 20,000$; 4) costeffective: $€ 20,000<$ ICERs $\leq € 40,000$; 5) not cost-effective: ICERs $>€ 40,000$. The classification was based on both literature and suggestions in identified studies in this review [30,31].

\section{Results}

Up to October 2011, 434 articles (141 articles from PubMed and 293 articles from EMBASE) were identified. After full-text checking, 32 articles were included into the quality assessment. After quality assessment, 30 articles were finally included in this review (Figure 1). One of the 


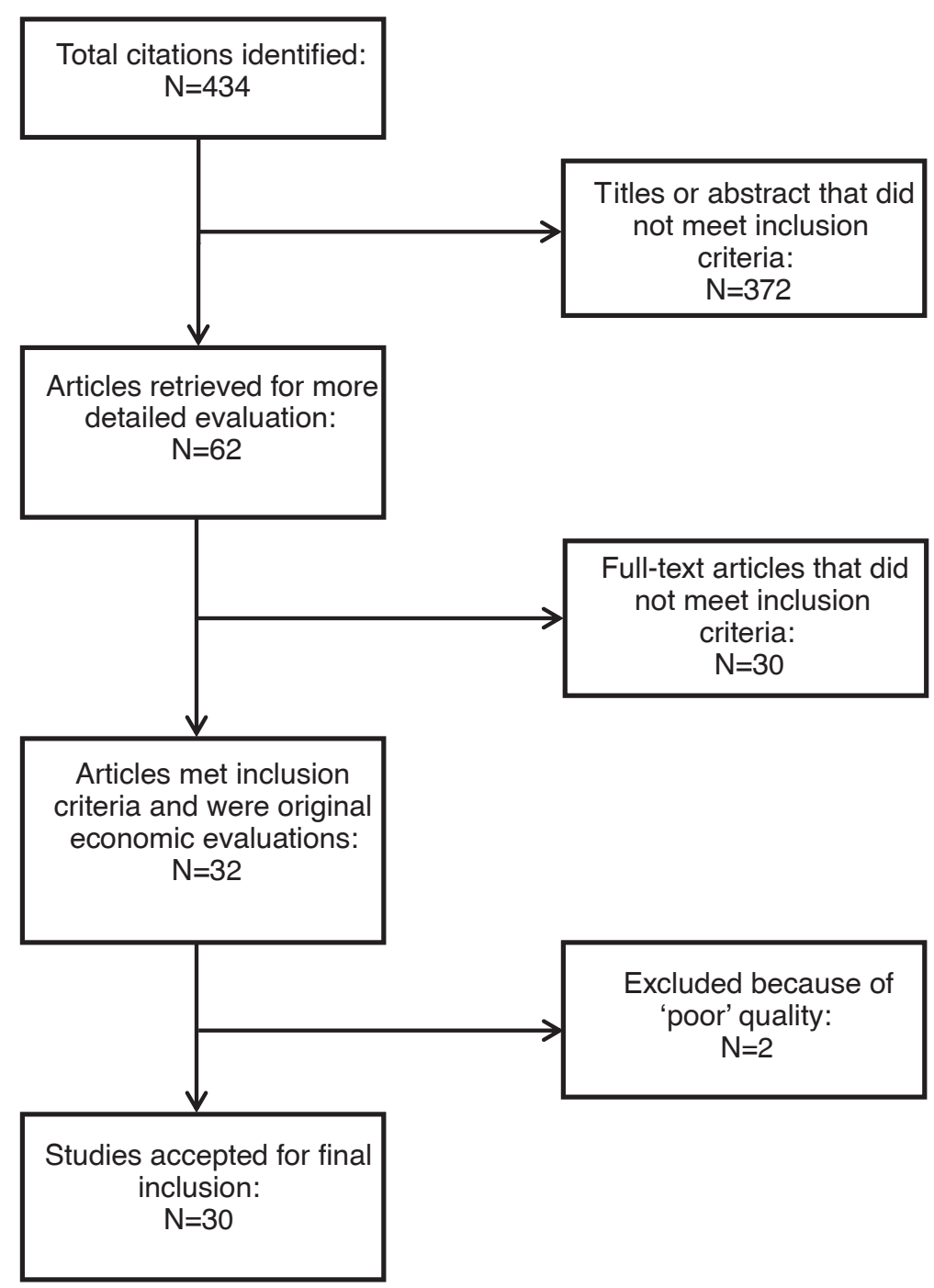

Figure 1 Flow chart summarizing systematic study selection process.

excluded articles had 4 criteria assessed as inadequate and only 4 criteria assessed as good. The other one merely got 5 criteria rated as adequate among the 11 criteria considered.

Among these 30 selected articles, in one article on losartan for an Asian population [32] only the data from Hong Kong were considered as the cost data from other Asian countries or regions assessed seemed not to be of adequate quality. Finally, 39 studies in different countries or regions contained in these 30 articles were included in the analysis.

\section{Summary of selected studies}

Table 2 summarizes the basic features of studies included. All six ACEIs studies [33-38] were literaturebased evaluations which synthesized data from different sources. All ARBs studies [32,39-62] were designed based on specific trials. The Markov model was the most common decision analytic method used in these evaluations. From the cost-effectiveness results, 37 out of 39 studies indicated both ACEIs and ARBs were cost-saving comparing with placebo/conventional treatment or amlodipine. In the absence of clear cost savings, cost neutrality of very favorable cost-effectiveness was achieved minimally. No studies were identified with a direct cost-effectiveness comparison between ACEIs and ARBs.

\section{Design of selected studies}

Key features of the design of the selected studies were summarized in Table 3. Six studies of ACEIs [33-38] were diverse in data sources, intervention and control groups. The 33 studies on ARBs showed much more consistency within each ARB drug class (losartan, irbesartan and valsartan) regarding control and data 
Table 2 Summary of selected studies (number of study)

\begin{tabular}{|c|c|c|c|c|c|c|}
\hline & & $\begin{array}{l}\text { ACEls } \\
\text { (total 6) }\end{array}$ & $\begin{array}{l}\text { ARBs } \\
\text { (total 33) }\end{array}$ & $\begin{array}{l}\text { ARBs Losartan } \\
\text { (total 14) }\end{array}$ & $\begin{array}{l}\text { ARBs Irbesartan } \\
\text { (total 18) }\end{array}$ & $\begin{array}{l}\text { ARBs Valsartan } \\
\text { (total 1) }\end{array}$ \\
\hline \multirow[t]{2}{*}{ Data source } & Trial based & 0 & 33 & 14 & 18 & 1 \\
\hline & Literature based & 6 & 0 & 0 & 0 & 0 \\
\hline \multirow{3}{*}{$\begin{array}{l}\text { Intervention and } \\
\text { control group }\end{array}$} & Comparing with placebo/conventional therapy & 2 & 22 & 14 & 8 & 0 \\
\hline & Comparing with other drugs & 0 & 12 & 0 & 11 & 1 \\
\hline & Comparing different strategies & 4 & 10 & 0 & 10 & 0 \\
\hline \multirow[t]{3}{*}{ Decision model } & Markov model & 6 & 20 & 1 & 18 & 1 \\
\hline & Weibull model & 0 & 3 & 3 & 0 & 0 \\
\hline & Regression method & 0 & 10 & 10 & 0 & 0 \\
\hline \multirow[t]{2}{*}{ Perspective } & Third party payer & 4 & 33 & 14 & 18 & 1 \\
\hline & Societal & 2 & 0 & 0 & 0 & 0 \\
\hline \multirow[t]{5}{*}{ CE results } & Cost-saving & 5 & 32 & 13 & 18 & 1 \\
\hline & Cost-neutral & 0 & 1 & 1 & 0 & 0 \\
\hline & Very cost-effective & 1 & 0 & 0 & 0 & 0 \\
\hline & Cost-effective & 0 & 0 & 0 & 0 & 0 \\
\hline & Not cost-effective & 0 & 0 & 0 & 0 & 0 \\
\hline
\end{tabular}

sources concerning the various clinical trials done in ARBs.

\section{ACEIs}

Six studies [33-38] evaluated the cost-effectiveness of ACEIs, all using a Markov model as the method for decision modeling. The transition probabilities in these Markov models, i.e. the sources and sizes of effectiveness data in these studies, were diverse. All six studies obtained their effectiveness data from more than one RCT [63-67] or from meta-analyses [37,38]. Only one of the studies [34] included a specific ACEI, enalapril, to compare with placebo, while the other five studies treated ACEIs as a group or drug class. ARBs were also included in the analytic model as a substitute for ACEIs when patients got cough side-effect in the two articles written by Adarkwah et al. [37,38].

\section{ARBs}

The 33 studies (included in 24 articles [32,39-61]) targeting ARBs have major similarities in study design. Fourteen evaluations for losartan [32,39-47] were based on The Reduction of Endpoints in Non-insulin Dependent Diabetes Mellitus with the Angiotensin II Antagonist Losartan (RENAAL) trial [62]. Eighteen evaluations of irbesartan [48-60] used data from the Irbesartan in Diabetic Nephropathy Trial (IDNT) [68] to assess the cost-effectiveness for patients with type 2 diabetes and overt nephropathy before 2004. Later the Irbesartan in Reduction of Microalbuminuria-2 (IRMA-2) [69] trial was added into the model to expand the progress of diabetic renal development from nephropathy back to the onset of MiA. The only study for valsartan was based on the MicroAlbuminuria Reduction With VALsartan (MARVAL) study [70].

All 14 losartan studies can be subdivided into two groups based on different time horizon. Eleven studies $[32,39-42,46,47]$ were within-trial analyses, while the other three [43-45] extrapolated to beyond-trial timehorizon analyses. Ten within-trial analyses [32,39-42,47] used a straightforward method to calculate the effectiveness and cost. In this method, the patient-days spent in the stage of ESRD were estimated by subtracting the area under curve (AUC) of the Kaplan-Meier survival curve for time to the minimum of ESRD or all-cause death for both groups in the trial. The costs of ESRD were calculated by multiplying ESRD days and daily cost of ESRD. Only one within-trial study [46] performed a Markov model as the analytic method to evaluate the cost-effectiveness. Three beyond-trial studies [43-45] used a Weibull model to prolong the time horizon to lifetime. Cumulative incidence of ESRD and life expectancy were assessed as the effectiveness measurements.

Irbesartan for overt nephropathy was compared with conventional treatment and amlodipine in five studies [48-51]. These five studies were based on the IDNT trial and a Markov model with five stages (from 'overt nephropathy' via 'double of serum creatinine', 'ESRD + dialysis' and 'ESRD + transplant' to 'death') was developed to evaluate life expectancy and lifetime cost. In particular, Palmer et al. combined the IRMA-2 trial with the IDNT trial and applied a seven-stage Markov model, extrapolating the Markov model with a previous MiA state [48,49,51-60]. 'Early irbesartan' (standard antihypertensive therapy plus 
Table 3 Study design of economic evaluations on ACEIs and ARBs

\begin{tabular}{|c|c|c|c|c|c|c|}
\hline Study, country/region & $\begin{array}{l}\text { Source of } \\
\text { effectiveness } \\
\text { data }\end{array}$ & Intervention group & Control group & Decision model type & $\begin{array}{l}\text { Time } \\
\text { horizon } \\
\text { (years) }\end{array}$ & Evaluation type \\
\hline \multicolumn{7}{|l|}{ ACEls } \\
\hline \multirow{2}{*}{$\begin{array}{l}\text { Golan et al. } 1999 \text { US } \\
\text { [33] }\end{array}$} & \multirow{2}{*}{$\begin{array}{l}\text { UERNN, LEAPP } \\
\text { and EADN trial }\end{array}$} & \multirow[t]{2}{*}{ Treat all' strategy ${ }^{a}$} & (1) Screen for $M i A^{b}$; & \multirow[t]{2}{*}{ Markov model with 5 states } & \multirow[t]{2}{*}{10} & \multirow[t]{2}{*}{ CEA \& CUA (Life-years \& QALYS) } \\
\hline & & & $\begin{array}{l}\text { (2) Screen for gross } \\
\text { proteinuriac. }\end{array}$ & & & \\
\hline $\begin{array}{l}\text { Sakthong et al. } 2001 \\
\text { Thailand [34] }\end{array}$ & $\begin{array}{l}\text { LEAN trial and } \\
\text { the opinion of } \\
\text { nephrologists }\end{array}$ & $\begin{array}{l}\text { Enalapril at the dose of } 10 \mathrm{mg} / \\
\text { day }\end{array}$ & Placebo & Markov model with 4 stages & 25 & CEA (Life years) \\
\hline $\begin{array}{l}\text { Rosen et al. } 2005 \text { US } \\
\text { [35] }\end{array}$ & $\begin{array}{l}\text { UERNN, EADN, } \\
\text { LEAN, H-MH } \\
\text { studies and } \\
\text { HOPE trial }\end{array}$ & $\begin{array}{l}\text { Medicare first-dollar coverage of } \\
\text { ACEls }\end{array}$ & $\begin{array}{l}\text { Year 2005's Medicare } \\
\text { practice }\end{array}$ & $\begin{array}{l}\text { Markov model adding a cardiovascular } \\
\text { events component. }\end{array}$ & lifetime & CEA \& CUA (Life-years \& QALYs) \\
\hline $\begin{array}{l}\text { Campbell et al. } 2007 \text { US } \\
\text { [36] }\end{array}$ & $\begin{array}{l}\text { UERNN, EADN, } \\
\text { H-MH studies } \\
\text { and IRMA-2 trial }\end{array}$ & $\begin{array}{l}\text { ACEl therapy in } \\
\text { normoalbuminimuric, } \\
\text { microalbuminuric, and } \\
\text { macroalbuminuric patients }\end{array}$ & No ACEl initiation in patients & Markov model & 8 & $\begin{array}{l}\text { CEA (CVD event avoided, life } \\
\text { saved, dialysis prevented, } \\
\text { composite endpoint avoided) }\end{array}$ \\
\hline \multirow{3}{*}{$\begin{array}{l}\text { Adarkwah et al. } 2010 \\
\text { Germany [37] }\end{array}$} & \multirow{3}{*}{$\begin{array}{l}\text { EADN and two } \\
\text { meta-analyses }\end{array}$} & \multirow[t]{3}{*}{ Treat all' strategy ${ }^{a}$} & (1) Screen for $M i A^{b}$; & \multirow[t]{3}{*}{ Markov model with 5 states } & \multirow[t]{3}{*}{50} & \multirow[t]{3}{*}{ CUA (QALY) } \\
\hline & & & (2) Screen for $\mathrm{MaA}^{\mathrm{c}}$; & & & \\
\hline & & & $\begin{array}{l}\text { (3) no-screening and } \\
\text { no-treatment alternative. }\end{array}$ & & & \\
\hline \multirow{2}{*}{$\begin{array}{l}\text { Adarkwah et al. } 2011 \\
\text { Netherlands [38] }\end{array}$} & \multirow{2}{*}{$\begin{array}{l}\text { EADN and two } \\
\text { meta-analyses }\end{array}$} & \multirow[t]{2}{*}{ Treat all' strategy ${ }^{a}$} & (1) Screen for $M i A^{b}$; & \multirow[t]{2}{*}{ Markov model with 5 states } & \multirow[t]{2}{*}{50} & \multirow[t]{2}{*}{ CUA (QALY) } \\
\hline & & & (2) Screen for MaAc. & & & \\
\hline \multicolumn{7}{|l|}{ ARBs } \\
\hline \multicolumn{7}{|l|}{ Losartan } \\
\hline $\begin{array}{l}\text { Herman et al. } 2003 \text { US } \\
\text { [39] }\end{array}$ & RENAAL trial & Losartan & Placebo $^{d}$ & A regression-based method & $3.5 / 4$ & CEA (Number of ESRD days) \\
\hline $\begin{array}{l}\text { Souchet et al. } 2003 \\
\text { France [40] }\end{array}$ & RENAAL trial & $\begin{array}{l}\text { Losartan (initial daily dosing of } \\
\text { losartan was } 50 \mathrm{mg} \text {, with the } \\
\text { possibility of titration to } \\
100 \mathrm{mg} / \text { day) }\end{array}$ & Placebo $^{d}$ & A regression-based method & $3.5 / 4$ & CEA (Number of ESRD days) \\
\hline $\begin{array}{l}\text { Burgess et al. } 2004 \\
\text { Canada [41] }\end{array}$ & RENAAL trial & Losartan & Placebo $^{d}$ & A regression-based method & $3.5 / 4$ & CEA (Number of ESRD days) \\
\hline $\begin{array}{l}\text { Szucs et al. } 2004 \\
\text { Switzerland [42] }\end{array}$ & RENAAL trial & $\begin{array}{l}\text { Losartan (initial daily dosing of } \\
\text { losartan was } 50 \mathrm{mg} \text {, with the } \\
\text { possibility of titration to } \\
100 \mathrm{mg} / \text { day) }\end{array}$ & Placebo $^{d}$ & A regression-based method & $3.5 / 4$ & CEA (Number of ESRD days) \\
\hline $\begin{array}{l}\text { Seng et al. } 2005 \text { Hong } \\
\text { Kong [32] (only data of } \\
\text { Hong Kong were } \\
\text { included) }\end{array}$ & RENAAL trial & Losartan & Placebo $^{d}$ & A regression-based method & 3.5 & CEA (Number of ESRD days) \\
\hline
\end{tabular}

Hong Kong were

included) 
Table 3 Study design of economic evaluations on ACEls and ARBs (Continued)

\begin{tabular}{|c|c|c|c|c|c|c|}
\hline $\begin{array}{l}\text { Arredondo et al. } 2005 \\
\text { Mexico [43] }\end{array}$ & RENAAL trial & Losartan & Placebo $^{d}$ & $\begin{array}{l}\text { A variation of the cumulative incidence } \\
\text { competing risk method / Weibull model }\end{array}$ & $\begin{array}{l}25 \text { (life } \\
\text { time) }\end{array}$ & $\begin{array}{l}\text { CEA (Cumulative incidence of } \\
\text { ESRD, life expectancy) }\end{array}$ \\
\hline Vora et al. 2005 UK [44] & RENAAL trial & Losartan (50-100 mg QD) & $\begin{array}{l}\text { Conventional } \\
\text { antihypertensive treatment }{ }^{d} \\
\text { (excluding ACEls or } \\
\text { angiotensin II antagonists) }\end{array}$ & Weibull model & life time & $\begin{array}{l}\text { CEA (Cumulative incidence of } \\
\text { ESRD, life expectancy) }\end{array}$ \\
\hline $\begin{array}{l}\text { Carides et al. } 2006 \text { US } \\
\text { [45] }\end{array}$ & RENAAL trial & Losartan & Placebo $^{d}$ & $\begin{array}{l}\text { A cumulative incidence competing risk } \\
\text { method / Weibull model }\end{array}$ & $\begin{array}{l}25 \text { (life } \\
\text { time) }\end{array}$ & $\begin{array}{l}\text { CEA (Cumulative incidence of } \\
\text { ESRD, life expectancy) }\end{array}$ \\
\hline $\begin{array}{l}\text { Stafylas et al. } 2007 \\
\text { Greece [46] }\end{array}$ & RENAAL trial & Losartan (50-100 mg QD) & Placebo $^{d}$ & Markov model with 6 states & $3.5 / 4$ & CEA (Number of ESRD days) \\
\hline $\begin{array}{l}\text { de Portu et al. } 2011 \\
\text { Italy, France, Germany, } \\
\text { Switzerland, US [47] }\end{array}$ & RENAAL trial & Losartan & Standard care ${ }^{d}$ & $\begin{array}{l}\text { Standard methods by comparing the } \\
\text { economic outcomes deriving from } \\
\text { additional losartan to standard care vs } \\
\text { standard care alone }\end{array}$ & 3.4 & CEA (Number of ESRD days) \\
\hline \multicolumn{7}{|l|}{ Irbesartan } \\
\hline \multirow{2}{*}{$\begin{array}{l}\text { Rodby RA et al. } 2003 \\
\text { US [48] }\end{array}$} & \multirow[t]{2}{*}{ IDNT trial } & \multirow{2}{*}{$\begin{array}{l}\text { Irbesartan titrated from } 75 \text { to } \\
300 \mathrm{mg} / \text { day }\end{array}$} & (1) 'Control'd; & \multirow[t]{2}{*}{ Markov model with 5 stages } & \multirow[t]{2}{*}{25} & \multirow[t]{2}{*}{ CEA (Life expectancy) } \\
\hline & & & $\begin{array}{l}\text { (2) Amlodipine titrated from } \\
2.5 \text { to } 10 \mathrm{mg} / \text { day. }\end{array}$ & & & \\
\hline \multirow{2}{*}{$\begin{array}{l}\text { Palmer AJ et al. 2003 } \\
\text { Belgium, France [49] }\end{array}$} & \multirow[t]{2}{*}{ IDNT trial } & \multirow{2}{*}{$\begin{array}{l}\text { Irbesartan titrated from } 75 \text { to } \\
300 \mathrm{mg} / \text { day }\end{array}$} & (1) 'Control'd; & \multirow[t]{2}{*}{ Markov model with 5 stages } & \multirow[t]{2}{*}{25} & \multirow[t]{2}{*}{ CEA (Life expectancy) } \\
\hline & & & $\begin{array}{l}\text { (2) Amlodipine titrated from } \\
2.5 \text { to } 10 \mathrm{mg} / \text { day. }\end{array}$ & & & \\
\hline \multirow{2}{*}{$\begin{array}{l}\text { Coyle D et al. } 2004 \\
\text { Canada [50] }\end{array}$} & \multirow[t]{2}{*}{ IDNT trial } & \multirow[t]{2}{*}{ Irbessartan } & (1) Amlodipine; & \multirow[t]{2}{*}{ Markov model with 5 stages } & \multirow[t]{2}{*}{25} & \multirow[t]{2}{*}{ CEA (Life expectancy) } \\
\hline & & & (2) Standard care ${ }^{d}$ & & & \\
\hline \multirow{2}{*}{$\begin{array}{l}\text { Palmer AJ et al. } 2004 \\
\text { UK [51] }\end{array}$} & \multirow[t]{2}{*}{ IDNT trial } & \multirow[t]{2}{*}{ Irbesartan 300 mg per day } & (1) 'Control'd; & \multirow[t]{2}{*}{ Markov model with 5 stages } & \multirow[t]{2}{*}{25} & \multirow[t]{2}{*}{ CEA (Life expectancy) } \\
\hline & & & $\begin{array}{l}\text { (2) Amlodipine } 10 \mathrm{mg} \text { per } \\
\text { day. }\end{array}$ & & & \\
\hline \multirow{2}{*}{$\begin{array}{l}\text { Palmer AJ et al. } 2004 \\
\text { US [52] }\end{array}$} & \multirow{2}{*}{$\begin{array}{l}\text { IRMA-2 study } \\
\text { and IDNT }\end{array}$} & \multirow[t]{2}{*}{ 'Early irbesartan'e } & (1) 'Control'd; & \multirow[t]{2}{*}{ Markov model with 7 stages } & \multirow[t]{2}{*}{25} & \multirow{2}{*}{$\begin{array}{l}\text { CEA (Years free of ESRD, } \\
\text { cumulative incidence ESRD, life } \\
\text { expectancy) }\end{array}$} \\
\hline & & & (2) 'Late irbesartan'f & & & \\
\hline $\begin{array}{l}\text { Palmer AJ et al. } 2005 \\
\text { Spain [53] }\end{array}$ & $\begin{array}{l}\text { IRMA-2 study } \\
\text { and IDNT }\end{array}$ & 'Early irbesartan'e & $\begin{array}{l}\text { Standard antihypertensive } \\
\text { medications }\end{array}$ & Markov model with 7 stages & 25 & $\begin{array}{l}\text { CEA (Years free of ESRD, } \\
\text { cumulative incidence ESRD, life } \\
\text { expectancy) }\end{array}$ \\
\hline $\begin{array}{l}\text { Palmer AJ et al. } 2006 \\
\text { Switzerland [54] }\end{array}$ & $\begin{array}{l}\text { IRMA-2 study } \\
\text { and IDNT }\end{array}$ & 'Early irbesartan'e & $\begin{array}{l}\text { Conventional } \\
\text { antihypertensive treatment }^{d} \\
\text { initiated when patients had } \\
\text { developed MiA. }\end{array}$ & Markov model with 7 stages & 25 & $\begin{array}{l}\text { CEA (Years free of ESRD, } \\
\text { cumulative incidence of ESRD, life } \\
\text { expectancy) }\end{array}$ \\
\hline \multirow{2}{*}{$\begin{array}{l}\text { Palmer AJ et al. } 2006 \\
\text { France [55] }\end{array}$} & \multirow{2}{*}{$\begin{array}{l}\text { IRMA-2 study } \\
\text { and IDNT }\end{array}$} & \multirow[t]{2}{*}{ 'Early irbesartan'e } & (1) 'Control'd; & \multirow[t]{2}{*}{ Markov model with 7 stages } & 25 & CEA \& CUA (Years free of ESRD, \\
\hline & & & (2) 'Late irbesartan'f & & & life expectancy, QALY) \\
\hline $\begin{array}{l}\text { Palmer AJ et al. } 2007 \\
\text { Hungary [56] }\end{array}$ & $\begin{array}{l}\text { IRMA-2 study } \\
\text { and IDNT }\end{array}$ & 'Early irbesartan'e & $\begin{array}{l}\text { 'Placebo'd: standard } \\
\text { antihypertensive medications }\end{array}$ & Markov model with 7 stages & 25 & $\begin{array}{l}\text { CEA (Years free of ESRD, } \\
\text { cumulative incidence ESRD, life } \\
\text { expectancy) }\end{array}$ \\
\hline
\end{tabular}


initiated when patients

developed MiA.

Palmer AJ et al. 2007

IRMA-2 study

and IDNT trial

'Early irbesartan'e

(1) 'Control'd;

(2) 'Late irbesartan'f

Coyle D et al. 2007

Canada [58]

IRMA-2 study and IDNT

Yang W.C. et al. 2007

Taiwan [59]

RMA-2 study

and IDNT

Annemans et al. $2008 \quad$ IRMA-2 study

China, Taiwan, Malaysia, and IDNT trial

Thailand, South Korea

[60]

\section{Valsartan}

Smith DG et al. 2004 US MARVAL study Valsartan

a: no screening was performed at all and patients started on ACEl therapy at the time of diagnosing type 2 diabetes.

b: patients were screened for MiA once a year and ACEl treatment was started if the test result is positive.

c: patients were screened for MaA once a year and ACEl treatment was started if the test result is positive.

d: standard antihypertensive therapy alone, excluding the use of ACEls, ARBs.

e: standard antihypertensive therapy plus administration of irbesartan $300 \mathrm{mg} / \mathrm{d}$ at the onset of MiA.

f: standard antihypertensive therapy plus administration of irbesartan $300 \mathrm{mg} / \mathrm{d}$ once the patients reach the advanced diabetic nephropathy stage.

g: standard antihypertensive therapy plus administration of amlodipine titrated from 5 to $10 \mathrm{mg} / \mathrm{d}$ once the patients reach the advanced diabetic nephropathy stage.

UERNN = Use of enalapril to attenuate decline in renal function in normotensive, normoalbuminuric patients with type 2 diabetes mellitus; LEAPP = Long-term stabilizing effect of angiotensin-converting enzyme

inhibition on plasma creatinine and on proteinuria in normotensive type II diabetic patients; EADN = The effect of angiotensin-converting-enzyme inhibition on diabetic nephropathy; LEAN = Long-term renoprotective

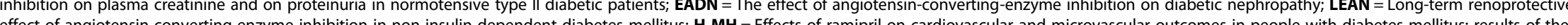

HOPE study and MICRO HOPE suztudy; HOPE = The Heart Outcomes Prevention Evaluation; RENAAL = The roduction of endpoints in non-insulin dependent diabetes mellitus with the angiotensin II antagults of the

HOPE study and MICRO-HOPE substudy; HOPE = The Heart Outcomes Prevention Evaluation; RENAAL = The reduction of endpoints in non-insulin dependent diabetes mellitus with the angiotensin II antagonist losartan

CEA = cost-effectiveness analysis: CUA $=$ cost-utility analysis. 
irbesartan at the onset of MiA) was then compared with conventional therapy and 'late irbesartan' or 'late amlodipine' (standard antihypertensive therapy plus administration of irbesartan/amlodipine once the patients reach the advanced diabetic nephropathy stage).

Cost-effectiveness of Valsartan [61] was evaluated in one study using amlodipine as the control. A Markov model with seven stages was designed and QALYs were calculated as the effectiveness results.

\section{Cost-effectiveness results}

The key features and main results of all included evaluations are summarized in Table 4.

\section{ACEls}

Of the six ACEIs' studies, two [33,35] adopted a societal perspective. This contained additional cost analyses including productivity gains and losses, caregiver time costs. The other four [34,36-38] took the third party payer/ health care perspective including only direct costs of nephropathy, ACEIs or other related treatment such as those for cardiovascular disease (CVD). All studies except one [33] favored ACEIs due to the cost-saving results. The exception was the evaluation from Golan et al. [33], showing that compared to 'screen for MiA' (patients were screened for MiA once a year and ACEI treatment was started if the test result is positive), the 'treat all' strategy with ACEIs (no screening was performed at all and patients started on ACEI therapy at the time of diagnosing type 2 diabetes) raised the costs by $\$ 300$, but the results still supported 'treat all' strategy as very cost-effective. -It should be noted that these positive results were based on the comparison between ACEIs and no blood pressure (BP) control treatment but not other $\mathrm{BP}$ control interventions.

\section{ARBs}

Based on the RENAAL trial, all the results over 3.5 years indicated losartan was cost-saving or cost-neutral (Hong Kong) [32] comparing to placebo/conventional therapy. The cost savings per patients ranged from $€ 2,079$ in Greece [46] to $€ 4,641$ in France [47]. When the time horizon was prolonged to lifetime or 25 years, beyondtrial studies showed that the net cost savings by adding losartan to conventional therapy were $€ 9,182$ in UK [44], $€ 1,861$ in Mexico [43] and $€ 22,757$ in U.S [45].

For irbesartan, results consistently showed cost-savings comparing with conventional therapy or amlodipine, even when already started at the onset of MiA. Such early start of irbesartan would economically be even more attractive as compared with late irbesartan starting at overt nephropathy. The five studies [48-51] based on the IDNT trial demonstrated that irbesartan for overt nephropathy could prolong life expectancy with 0.43 years (Canada)
[50] to 0.74 years (U.S.) [48] and save $€ 7,075$ (U.K.) [51] to $€ 19,132$ (France) [49] per patient comparing with control over 25 years. When the MiA stage was introduced into the model, early irbesartan remained cost-saving at $€ 2,564$ in Hungary [56] to $€ 57,871$ in Canada [58] compared with control, being more cost-saving than late irbesartan.

The only study for valsartan [61] also supported the using of ARBs in patients with type 2 diabetes and MiA because of saving QALYs and costs. Over 8 years, valsartan treatment had 0.555 discounted QALYs advantage over amlodipine with savings at $€ 30,424$ compared to amlodipine.

\section{Discussion}

To our knowledge, this is the first review that summarizes all information on the cost-effectiveness of both ACEIs and ARBs. Our systematic review confirms earlier results evidencing the cost-saving potentials of ARBs for type 2 diabetic patients with nephropathy compared with conventional therapy excluding a RAAS inhibitor. Also, our review shows that such potentials might even stronger exist in early treatments prior to the stage of nephropathy, for example, in the MiA-stage. In addition, we found similar cost-saving results for ACEIs due to avoidance of ESRD in combination with prolonging life expectancy. Differences in cost effectiveness of ACEI versus ARB could not be solidly established because of differences in model design, time horizon and country setting among all included studies and lack of head-tohead comparisons in economic evaluations. Yet, costsaving potentials were unequivocally assessed for both drug groups.

\section{Cost-effectiveness of ACEls}

The number of articles concerning ACEIs was limited compared with the number for ARBs. The reason for not basing studies on single clinical trials may be related to the chronology of ACEIs being available on the market, i.e. the 1980s, before the ARBs. The relevance of CVD in diabetes became only clear in 1990s when the benefits of RAAS inhibitors started also to become clear for diabetic patients. From the six articles included in this review, ACEIs were cost-saving in articles published after 2000s [34-38] and not cost saving (but very cost-effective) in the only one article before 2000s [33]. This may be explained by the patent protection of ACEIs which became generic in the late of 1990 s.

Three articles $[33,37,38]$ combined screening for MiA or $\mathrm{MaA}$ as the start time point of ACEIs treatment in their analyses. Previous studies of screening for albuminuria with subsequent ACEIs treatment on cardiovascular and renal diseases also support the conclusions on favorable cost-effectiveness and early treatments. Atthobari et al. [71] found that the estimated cost-effectiveness of 
Table 4 Main results of economic evaluations on ACEls and ARBs

\begin{tabular}{|c|c|c|c|c|c|c|c|c|}
\hline \multirow[t]{2}{*}{$\begin{array}{l}\text { Study, country/ } \\
\text { region }\end{array}$} & \multicolumn{2}{|c|}{$\begin{array}{l}\text { Discount rate } \\
\text { (per annum) }\end{array}$} & \multirow{2}{*}{ Perspective } & \multirow[t]{2}{*}{ Cost categories } & \multirow[t]{2}{*}{ Discounted life expectancy/QALY } & \multirow{2}{*}{$\begin{array}{l}\text { Incremental cost } \\
\text { per patients } \\
\text { [year of value] }\end{array}$} & \multirow{2}{*}{$\begin{array}{l}\text { Incremental cost } \\
\text { per patients } \\
\text { (standardized } \\
\text { to } 2011 \text { Euro) }\end{array}$} & \multirow[t]{2}{*}{$\begin{array}{l}\text { CE with } \\
\text { interventions }\end{array}$} \\
\hline & $\begin{array}{l}\text { Effects } \\
(\%)\end{array}$ & $\begin{array}{l}\text { Costs } \\
(\%)\end{array}$ & & & & & & \\
\hline \multicolumn{9}{|l|}{ ACEls } \\
\hline \multirow{2}{*}{$\begin{array}{l}\text { Golan et al. } \\
1999 \text { US [33] }\end{array}$} & \multirow[t]{2}{*}{3} & \multirow[t]{2}{*}{3} & \multirow[t]{2}{*}{ Societal } & \multirow{2}{*}{$\begin{array}{l}\text { The cost of ESRD (dialysis \& } \\
\text { transplant), ACEls and } \\
\text { screening }\end{array}$} & 15.63 years/11.82 QALYs with 'treat all', & \multirow{2}{*}{$\begin{array}{l}\text { Treat all' vs 'screen for } \\
\text { MiA': } \$ 300^{a}\end{array}$} & \multirow{2}{*}{$\begin{array}{l}\text { Treat all' vs 'screen } \\
\text { for MiA': } € 299\end{array}$} & \multirow{2}{*}{$\begin{array}{l}\text { Very cost-effective } \\
\text { ['Treat all' vs. } \\
\text { 'screen for MiA': } \\
\text { €8,062/QALY] }\end{array}$} \\
\hline & & & & & $\begin{array}{l}15.59 \text { years/11.78 QALYs with 'screen for } \\
\text { MiA', } 15.39 \text { years/11.59 QALYS with } \\
\text { 'screen for gross proteinuria' }\end{array}$ & & & \\
\hline $\begin{array}{l}\text { Sakthong et al. } \\
\text { 2001 Thailand } \\
\text { [34] }\end{array}$ & 8 & 8 & Not mentioned & $\begin{array}{l}\text { The cost of ESRD } \\
\text { (haemodialysis) and ACEI }\end{array}$ & $\begin{array}{l}9.04 \text { years with enalapril, } 7.54 \text { years with } \\
\text { control }\end{array}$ & $-\$ 1,198[1999]$ & $-€ 1,269$ & $\begin{array}{l}\text { Cost saving } \\
\text { [Enalapril] }\end{array}$ \\
\hline \multirow[t]{2}{*}{$\begin{array}{l}\text { Rosen et al. } 2005 \\
\text { US [35] }\end{array}$} & \multirow[t]{2}{*}{3} & \multirow[t]{2}{*}{3} & \multirow[t]{2}{*}{$\begin{array}{l}\text { Medicare and } \\
\text { societal }\end{array}$} & $\begin{array}{l}\text { (1) Medicare perspective: direct } \\
\text { medical costs and future health } \\
\text { care costs. }\end{array}$ & \multirow[t]{2}{*}{$\begin{array}{l}10.55 \text { years/8.36 QALYs with Medicare } \\
\text { first-dollar coverage of ACEIs, } 10.30 \text { years } \\
\text { /8.13 QALYs with at the time practice }\end{array}$} & \multirow[t]{2}{*}{$-\$ 1,606[2003]$} & \multirow[t]{2}{*}{$-€ 1,453$} & \multirow[t]{2}{*}{$\begin{array}{l}\text { Cost saving } \\
\text { [Medicare first- } \\
\text { dollar coverage of } \\
\text { ACEls] }\end{array}$} \\
\hline & & & & $\begin{array}{l}\text { (2) Societal perspective: } \\
\text { additional analyses included } \\
\text { productivity gains and losses, } \\
\text { caregiver time costs }\end{array}$ & & & & \\
\hline \multirow[t]{2}{*}{$\begin{array}{l}\text { Campbell et al. } \\
2007 \text { US [36] }\end{array}$} & \multirow[t]{2}{*}{3} & \multirow[t]{2}{*}{3} & \multirow[t]{2}{*}{ Health payer } & \multirow[t]{2}{*}{$\begin{array}{l}\text { Direct medical costs of } \\
\text { nephropathy, CVD, and ACEls }\end{array}$} & & \multirow{2}{*}{$\begin{array}{l}-\$ 772 \text { for } \\
\text { normoalbuminuria on } \\
\text { diagnosis, }-\$ 7,098 \text { for } \\
\text { MiA on diagnosis, } \\
\$ 7,987 \text { for MaA on diag- } \\
\text { nosis [2005] }\end{array}$} & \multirow{2}{*}{$\begin{array}{l}-€ 658 \text { for } \\
\text { normoalbuminuria on } \\
\text { diagnosis, - } 66,048 \text { for } \\
\text { MiA on diagnosis, } \\
€ 6,806 \text { for MaA on } \\
\text { diagnosis }\end{array}$} & $\begin{array}{l}\text { Cost-neutral [ACEls } \\
\text { used on } \\
\text { normoalbuminuria] }\end{array}$ \\
\hline & & & & & & & & $\begin{array}{l}\text { Cost saving [ACEls } \\
\text { on MiA] }\end{array}$ \\
\hline \multirow{2}{*}{$\begin{array}{l}\text { Adarkwah et al. } \\
2010 \text { Germany } \\
\text { [37] }\end{array}$} & \multirow[t]{2}{*}{3} & \multirow[t]{2}{*}{3} & \multirow{2}{*}{$\begin{array}{l}\text { the German } \\
\text { statutory health } \\
\text { insurance }\end{array}$} & $\begin{array}{l}\text { The cost of ESRD (dialysis \& } \\
\text { transplant), ACEls, ARBs and }\end{array}$ & 15.21 QALYs with 'treat all', & $\begin{array}{l}\text { 'Treat all' vs. 'placebo': } \\
\in 16024[2006]\end{array}$ & 'Treat all' vs. 'placebo': & Cost saving [Treat \\
\hline & & & & screening & $\begin{array}{l}\text { 15.14 QALYs with 'screen for MiA', } 14.83 \\
\text { QALYs with 'screen for MaA', } 14.46 \\
\text { QALYs with 'placebo' }\end{array}$ & & & \\
\hline $\begin{array}{l}\text { Adarkwah et al. } \\
2011 \text { Netherlands } \\
\text { [38] }\end{array}$ & 1.5 & 4 & Health care & $\begin{array}{l}\text { The cost of ESRD (dialysis \& } \\
\text { transplant), ACEIs, ARBs and } \\
\text { screening }\end{array}$ & $\begin{array}{l}\text { 19.63 QALYs with 'treat all', } 19.54 \text { QALYs } \\
\text { with 'screen for MiA', } 19.15 \text { with 'screen } \\
\text { for MaA' }\end{array}$ & $\begin{array}{l}\text { Treat all' vs. 'screen for } \\
\text { MiA': } € 2,719, \text { 'treat all' } \\
\text { vs. 'screen for MaA': } \\
-€ 12,356[2010]\end{array}$ & $\begin{array}{l}\text { Treat all' vs. 'screen } \\
\text { for MiA': } € 2,749 \text {, 'treat } \\
\text { all' vs. 'screen for } \\
\text { MaA': } € 12,492\end{array}$ & $\begin{array}{l}\text { Cost saving [Treat } \\
\text { all using ACEls] }\end{array}$ \\
\hline ARBs & & & & & & & & \\
\hline Losartan & & & & & & & & \\
\hline $\begin{array}{l}\text { Herman WH } \\
\text { et al., } 2003 \text { US } \\
\text { [39] }\end{array}$ & none & 3 & $\begin{array}{l}\text { Health care } \\
\text { system }\end{array}$ & $\begin{array}{l}\text { The cost of ESRD } \\
\text { (hemodialysis) and losartan } \\
\text { therapy }\end{array}$ & & $\begin{array}{l}\text { Over } 3.5 \text { years: }-\$ 3,522 \\
{[2001]}\end{array}$ & Over 3.5 years: $-€ 3,306$ & $\begin{array}{l}\text { Cost saving } \\
\text { [losartan] }\end{array}$ \\
\hline $\begin{array}{l}\text { Souchet T et al., } \\
2003 \text { France }[40]\end{array}$ & none & $8.1 \%^{\mathrm{b}}$ & $\begin{array}{l}\text { French health } \\
\text { care system }\end{array}$ & $\begin{array}{l}\text { The cost of ESRD (dialysis) and } \\
\text { losartan therapy }\end{array}$ & & $\begin{array}{l}\text { Over } 3.5 \text { years: }-€ 3,863 \\
\text { [2002] }\end{array}$ & Over 3.5 years: $-€ 4,522$ & $\begin{array}{l}\text { Cost saving } \\
\text { [losartan] }\end{array}$ \\
\hline
\end{tabular}


Table 4 Main results of economic evaluations on ACEls and ARBs (Continued)

\begin{tabular}{|c|c|c|c|c|c|c|c|c|}
\hline $\begin{array}{l}\text { Burgess ED et al., } \\
2004 \text { Canada [41] }\end{array}$ & none & none & $\begin{array}{l}\text { Health care } \\
\text { system }\end{array}$ & $\begin{array}{l}\text { The cost of ESRD (dialysis } \\
\& \text { transplant) and losartan } \\
\text { therapy }\end{array}$ & & Over 3.5 years: $-\$ 3,675^{a}$ & Over 3.5 years: - €3,368 & $\begin{array}{l}\text { Cost saving } \\
\text { [losartan] }\end{array}$ \\
\hline $\begin{array}{l}\text { Szucs TD et al., } \\
\text { 2004 Switzerland } \\
\text { [42] }\end{array}$ & none & none & $\begin{array}{l}\text { Swiss health } \\
\text { care payer }\end{array}$ & $\begin{array}{l}\text { The cost of ESRD (dialysis } \\
\& \text { transplant) and losartan } \\
\text { therapy (only the insurance- } \\
\text { paid part) }\end{array}$ & & $\begin{array}{l}\text { Over } 3.5 \text { years: } \\
\text {-CHF4,084 }\end{array}$ & Over 3.5 years: $-€ 3,660$ & $\begin{array}{l}\text { Cost saving } \\
\text { [losartan] }\end{array}$ \\
\hline $\begin{array}{l}\text { Seng WK et al., } \\
2005 \text { Hong Kong } \\
\text { [32] (only data of } \\
\text { Hong Kong were } \\
\text { included) }\end{array}$ & 3 & 3 & $\begin{array}{l}\text { Health care } \\
\text { system }\end{array}$ & $\begin{array}{l}\text { The cost of ESRD (dialysis) and } \\
\text { losartan therapy }\end{array}$ & & $-\$ 515[2004]$ & $-€ 413$ & $\begin{array}{l}\text { Cost-neutral } \\
\text { [losartan] }\end{array}$ \\
\hline $\begin{array}{l}\text { Arredondo A } \\
\text { et al., 2005 } \\
\text { Mexico [43] }\end{array}$ & 3 & 3 & $\begin{array}{l}\text { Health care } \\
\text { system }\end{array}$ & $\begin{array}{l}\text { The cost of ESRD (dialysis), } \\
\text { diabetes and losartan therapy }\end{array}$ & 0.697 life years gained for losartan & $-M \$ 24,073[2004]$ & $-€ 1,861$ & $\begin{array}{l}\text { Cost saving } \\
\text { [losartan] }\end{array}$ \\
\hline $\begin{array}{l}\text { Vora J et al., } 2005 \\
\text { UK [44] }\end{array}$ & 3.5 & 3.5 & $\begin{array}{l}\text { The UK National } \\
\text { Health Service } \\
\text { (NHS) }\end{array}$ & $\begin{array}{l}\text { The cost of ESRD (dialysis) and } \\
\text { losartan therapy }\end{array}$ & $\begin{array}{l}7.82 \text { life years with losartan, } 7.38 \text { life } \\
\text { years with placebo ( } 0.44 \text { life years } \\
\text { gained for losartan) }\end{array}$ & $-£ 6,622[2004]$ & $-€ 9,182$ & $\begin{array}{l}\text { Cost saving } \\
\text { [losartan] }\end{array}$ \\
\hline $\begin{array}{l}\text { Carides GW et al., } \\
2006 \text { US [45] }\end{array}$ & 3 & 3 & $\begin{array}{l}\text { Health care } \\
\text { system }\end{array}$ & $\begin{array}{l}\text { The cost of ESRD (dialysis), } \\
\text { diabetes and losartan therapy }\end{array}$ & 0.697 life years gained for losartan & $-\$ 24,632[2002]$ & $-€ 22,757$ & $\begin{array}{l}\text { Cost saving } \\
\text { [losartan] }\end{array}$ \\
\hline $\begin{array}{l}\text { Stafylas PC et al., } \\
2007 \text { Greece [46] }\end{array}$ & 3 & 3 & $\begin{array}{l}\text { The Greek } \\
\text { social insurance } \\
\text { system }\end{array}$ & $\begin{array}{l}\text { The cost of ESRD (dialysis \& } \\
\text { transplant) and } 75 \% \text { of drug } \\
\text { treatment costs }\end{array}$ & & $\begin{array}{l}\text { Over } 3.5 \text { years: } \\
-€ 1,665.43[2003]\end{array}$ & Over 3.5 years: $-€ 2,079$ & $\begin{array}{l}\text { Cost saving } \\
\text { [losartan] }\end{array}$ \\
\hline $\begin{array}{l}\text { de Portu S et al., } \\
2011 \text { Italy [47] }\end{array}$ & 3 & 3 & $\begin{array}{l}\text { National } \\
\text { Health care } \\
\text { Service }\end{array}$ & $\begin{array}{l}\text { The cost of ESRD } \\
\text { (hemodialysis) and losartan } \\
\text { therapy }\end{array}$ & & $-€ 3,602.98[2009]$ & $-€ 3,664$ & $\begin{array}{l}\text { Cost saving } \\
\text { [losartan] }\end{array}$ \\
\hline $\begin{array}{l}\text { de Portu S et al., } \\
2011 \text { France [47] }\end{array}$ & 3 & 3 & $\begin{array}{l}\text { Health } \\
\text { Insurance }\end{array}$ & $\begin{array}{l}\text { The cost of ESRD } \\
\text { (hemodialysis) and losartan } \\
\text { therapy }\end{array}$ & & $-€ 4,531.35[2009]$ & $-€ 4,641$ & $\begin{array}{l}\text { Cost saving } \\
\text { [losartan] }\end{array}$ \\
\hline $\begin{array}{l}\text { de Portu S et al., } \\
2011 \text { Germany } \\
{[47]}\end{array}$ & 3 & 3 & $\begin{array}{l}\text { Health } \\
\text { Insurance }\end{array}$ & $\begin{array}{l}\text { The cost of ESRD } \\
\text { (hemodialysis) and losartan } \\
\text { therapy }\end{array}$ & & $-€ 3,019.66[2009]$ & $-€ 3,062$ & $\begin{array}{l}\text { Cost saving } \\
\text { [losartan] }\end{array}$ \\
\hline $\begin{array}{l}\text { de Portu S et al., } \\
\text { 2011 Switzerland } \\
\text { [47] }\end{array}$ & 3 & 3 & $\begin{array}{l}\text { Medical } \\
\text { Insurance }\end{array}$ & $\begin{array}{l}\text { The cost of ESRD } \\
\text { (hemodialysis) and losartan } \\
\text { therapy }\end{array}$ & & $-€ 3,949.50[2009]$ & $-€ 3,977$ & $\begin{array}{l}\text { Cost saving } \\
\text { [losartan] }\end{array}$ \\
\hline $\begin{array}{l}\text { de Portu S et al., } \\
2011 \text { US [47] }\end{array}$ & 3 & 3 & $\begin{array}{l}\text { Centers for } \\
\text { Medicare \& } \\
\text { Medicaid } \\
\text { Services }\end{array}$ & $\begin{array}{l}\text { The cost of ESRD } \\
\text { (hemodialysis) and losartan } \\
\text { therapy }\end{array}$ & & $-€ 3,855.50[2009]$ & $-€ 4,007$ & $\begin{array}{l}\text { Cost saving } \\
\text { [losartan] }\end{array}$ \\
\hline \multicolumn{9}{|l|}{ Irbesartan } \\
\hline $\begin{array}{l}\text { Rodby RA et al., } \\
2003 \text { US [48] }\end{array}$ & 3 & 3 & $\begin{array}{l}\text { Health care } \\
\text { system }\end{array}$ & $\begin{array}{l}\text { The cost of ESRD (dialysis \& } \\
\text { transplant), hospitalizations, } \\
\text { irbesartan \& concomitant }\end{array}$ & $\begin{array}{l}8.225 \text { years with irbesartan, } 7.484 \text { years } \\
\text { with control ( } 0.741 \text { years gained for } \\
\text { irbesartan) }\end{array}$ & $-\$ 15,607[2000]$ & $-€ 14,987$ & $\begin{array}{l}\text { Cost saving } \\
\text { [irbesartan] }\end{array}$ \\
\hline
\end{tabular}


Table 4 Main results of economic evaluations on ACEls and ARBs (Continued)

\begin{tabular}{|c|c|c|c|c|c|c|c|c|}
\hline $\begin{array}{l}\text { Palmer AJ et al., } \\
2003 \text { Belgium } \\
\text { [49] }\end{array}$ & 3 & 3 & $\begin{array}{l}\text { Institut National } \\
\text { d'Assurance de } \\
\text { Maladie et } \\
\text { Invalidite' } \\
\text { (INAMI) }\end{array}$ & $\begin{array}{l}\text { The cost of ESRD (dialysis \& } \\
\text { transplant) and irbesartan \& } \\
\text { concomitant antihypertensive } \\
\text { drugs }\end{array}$ & $\begin{array}{l}8.57 \text { years with irbesartan, } 7.95 \text { years } \\
\text { with control ( } 0.62 \text { years gained for } \\
\text { irbesartan) }\end{array}$ & $-€ 11,885[2002]$ & $-€ 14,231$ & $\begin{array}{l}\text { Cost saving } \\
\text { [irbesartan] }\end{array}$ \\
\hline $\begin{array}{l}\text { Palmer AJ et al., } \\
2003 \text { France [49] }\end{array}$ & 3 & 3 & Social security & $\begin{array}{l}\text { The cost of ESRD (dialysis \& } \\
\text { transplant) and irbesartan \& } \\
\text { concomitant antihypertensive } \\
\text { drugs }\end{array}$ & $\begin{array}{l}8.58 \text { years with irbesartan, } 7.97 \text { years } \\
\text { with control ( } 0.61 \text { years gained for } \\
\text { irbesartan) }\end{array}$ & $-€ 16,345$ [2002] & $-€ 19,132$ & $\begin{array}{l}\text { Cost saving } \\
\text { [irbesartan] }\end{array}$ \\
\hline $\begin{array}{l}\text { Coyle D et al., } \\
2004 \text { Canada [50] }\end{array}$ & 5 & 5 & $\begin{array}{l}\text { Third party } \\
\text { payer }\end{array}$ & $\begin{array}{l}\text { The cost of ESRD (dialysis \& } \\
\text { transplant), irbesartan \& } \\
\text { concomitant antihypertensive } \\
\text { drugs and other medical costs }\end{array}$ & $\begin{array}{l}6.80 \text { years with irbesartan, } 6.37 \text { years } \\
\text { with control ( } 0.43 \text { years gained for } \\
\text { irbesartan) }\end{array}$ & -CAD12,564 [2001] & $-€ 11,457$ & $\begin{array}{l}\text { Cost saving } \\
\text { [irbesartan] }\end{array}$ \\
\hline $\begin{array}{l}\text { Palmer AJ et al., } \\
2004 \text { UK [51] }\end{array}$ & 1.5 & 6 & $\begin{array}{l}\text { National Health } \\
\text { Service (NHS) } \\
\text { payer }\end{array}$ & $\begin{array}{l}\text { The cost of ESRD (dialysis \& } \\
\text { transplant) and irbesartan \& } \\
\text { concomitant antihypertensive } \\
\text { drugs }\end{array}$ & $\begin{array}{l}0.58 \text { years gained for irbesartan vs } \\
\text { control }\end{array}$ & $-£ 4,978^{\mathrm{a}}$ & $-€ 7,075$ & $\begin{array}{l}\text { Cost saving } \\
\text { [irbesartan] }\end{array}$ \\
\hline $\begin{array}{l}\text { Palmer AJ et al., } \\
2004 \text { US [52] }\end{array}$ & 3 & 3 & $\begin{array}{l}\text { Third party } \\
\text { reimbursement }\end{array}$ & $\begin{array}{l}\text { The cost of ESRD (dialysis \& } \\
\text { transplant) and irbesartan }\end{array}$ & $\begin{array}{l}11.46 \text { years with 'early irbesartan', } \\
10.54 \text { years with 'late irbesartan', } \\
10.50 \text { years with control ( } 0.96 \text { years } \\
\text { gained for irbesartan vs control) }\end{array}$ & $\begin{array}{l}\text { Early irbesartan vs. } \\
\text { control: }-\$ 11,922 \text {, late } \\
\text { irbesartan vs. control: } \\
-\$ 3,252[2000]\end{array}$ & $\begin{array}{l}\text { Early irbesartan vs. } \\
\text { control: }-€ 11,448 \text {, late } \\
\text { irbesartan vs. control: } \\
-€ 3,123\end{array}$ & $\begin{array}{l}\text { Cost saving [early } \\
\text { irbesartan] }\end{array}$ \\
\hline $\begin{array}{l}\text { Palmer AJ et al., } \\
2005 \text { Spain [53] }\end{array}$ & 3 & 3 & $\begin{array}{l}\text { Third party } \\
\text { payer }\end{array}$ & $\begin{array}{l}\text { The cost of ESRD (dialysis \& } \\
\text { transplant) and irbesartan }\end{array}$ & $\begin{array}{l}12.37 \text { years with 'early irbesartan', } \\
11.53 \text { years with control ( } 0.84 \text { years } \\
\text { gained for irbesartan) }\end{array}$ & $-€ 11,082^{\mathrm{a}}$ & $-€ 12,971$ & $\begin{array}{l}\text { Cost saving [early } \\
\text { irbesartan] }\end{array}$ \\
\hline $\begin{array}{l}\text { Palmer AJ et al., } \\
2006 \text { Switzerland } \\
\text { [54] }\end{array}$ & 5 & 5 & $\begin{array}{l}\text { Third party } \\
\text { Swiss health } \\
\text { insurance payer }\end{array}$ & $\begin{array}{l}\text { The cost of ESRD (dialysis \& } \\
\text { transplant) and irbesartan }\end{array}$ & $\begin{array}{l}10.37 \text { years with 'early irbesartan', } \\
9.80 \text { years with control ( } 0.57 \text { years } \\
\text { gained for irbesartan) }\end{array}$ & -CHF21,487 [2003] & $-€ 19,257$ & $\begin{array}{l}\text { Cost saving [early } \\
\text { irbesartan] }\end{array}$ \\
\hline $\begin{array}{l}\text { Palmer AJ et al., } \\
2006 \text { France [55] }\end{array}$ & 3 & 3 & $\begin{array}{l}\text { Third party } \\
\text { French social } \\
\text { security } \\
\text { insurance payer }\end{array}$ & $\begin{array}{l}\text { The cost of ESRD (dialysis \& } \\
\text { transplant) and irbesartan }\end{array}$ & $\begin{array}{l}12.17 \text { years /10.55 QALYs with 'early } \\
\text { irbesartan', } 11.27 \text { years } / 9.58 \text { QALYS with } \\
\text { 'late irbesartan', } 11.23 \text { years } / 9.52 \text { QALYS } \\
\text { with control ( } 0.94 \text { years / } 1.03 \text { QALYS } \\
\text { gained for irbesartan vs control) }\end{array}$ & $\begin{array}{l}\text { 'Early irbesartan' vs. } \\
\text { control: - } € 22,314 \text {, 'late } \\
\text { irbesartan vs. control': } \\
-€ 6,619 \text { [2002] }\end{array}$ & $\begin{array}{l}\text { 'Early irbesartan' vs. } \\
\text { control: }-€ 26,119 \text {, 'late } \\
\text { irbesartan' vs. control: } \\
-€ 7,748\end{array}$ & $\begin{array}{l}\text { Cost saving [early } \\
\text { irbesartan] }\end{array}$ \\
\hline $\begin{array}{l}\text { Palmer AJ et al., } \\
2007 \text { Hungary } \\
\text { [56] }\end{array}$ & 5 & 5 & $\begin{array}{l}\text { Third-party } \\
\text { Hungarian } \\
\text { health } \\
\text { insurance payer }\end{array}$ & $\begin{array}{l}\text { The cost of ESRD (dialysis \& } \\
\text { transplant) and irbesartan }\end{array}$ & $\begin{array}{l}8.16 \text { years with 'early irbesartan', } \\
7.62 \text { years with control ( } 0.54 \text { years } \\
\text { gained for irbesartan) }\end{array}$ & -HUF519,993 [2002] & $-€ 2,564$ & $\begin{array}{l}\text { Cost saving [early } \\
\text { irbesartan] }\end{array}$ \\
\hline $\begin{array}{l}\text { Palmer AJ, } 2007 \\
\text { UK [57] }\end{array}$ & 3.5 & 3.5 & $\begin{array}{l}\text { Third party UK } \\
\text { National Health } \\
\text { Service (NHS) } \\
\text { payer }\end{array}$ & $\begin{array}{l}\text { The cost of ESRD (dialysis \& } \\
\text { transplant) and irbesartan }\end{array}$ & $\begin{array}{l}11.00 \text { years with 'early irbesartan', } \\
10.20 \text { years with 'late irbesartan', } \\
10.18 \text { years with control ( } 0.82 \text { years } \\
\text { gained for irbesartan vs control) }\end{array}$ & $\begin{array}{l}\text { 'Early irbesartan' vs. } \\
\text { control: - } £ 3,801 \text {, 'late } \\
\text { irbesartan' vs. control:- } \\
£ 1,491 \text { [2002] }\end{array}$ & $\begin{array}{l}\text { 'Early irbesartan' vs. } \\
\text { control: }-€ 5,532 \text {, 'late } \\
\text { irbesartan' vs. control: } \\
-€ 2,170\end{array}$ & $\begin{array}{l}\text { Cost saving [early } \\
\text { irbesartan] }\end{array}$ \\
\hline $\begin{array}{l}\text { Coyle D et al., } \\
2007 \text { Canada [58] }\end{array}$ & 5 & 5 & $\begin{array}{l}\text { Canadian } \\
\text { health and } \\
\text { social care } \\
\text { system }\end{array}$ & $\begin{array}{l}\text { All direct costs, including the } \\
\text { costs of health, social services, } \\
\text { long-term care. }\end{array}$ & $\begin{array}{l}11.52 \text { years with 'early irbesartan', } \\
11.06 \text { years with 'late irbesartan', } \\
10.90 \text { years with control ( } 0.62 \text { years } \\
\text { gained for irbesartan vs control) }\end{array}$ & $\begin{array}{l}\text { 'Early irbesartan' vs. } \\
\text { control: -CAD68,400, } \\
\text { 'late irbesartan' vs. con- } \\
\text { trol: -CAD14,300 [2006] }\end{array}$ & $\begin{array}{l}\text { 'Early irbesartan' vs. } \\
\text { control: }-€ 57,871 \text {, 'late } \\
\text { irbesartan' vs. control: } \\
-€ 12,099\end{array}$ & $\begin{array}{l}\text { Cost saving [early } \\
\text { irbesartan] }\end{array}$ \\
\hline
\end{tabular}


Table 4 Main results of economic evaluations on ACEls and ARBs (Continued)

\begin{tabular}{|c|c|c|c|c|c|c|c|c|}
\hline $\begin{array}{l}\text { Yang W.C. et al., } \\
2007 \text { Taiwan [59] }\end{array}$ & 3 & 3 & $\begin{array}{l}\text { Third-party } \\
\text { payer in Taiwan } \\
\text { (Taiwan } \\
\text { National Health } \\
\text { Insurance } \\
\text { Program) }\end{array}$ & $\begin{array}{l}\text { The cost of ESRD (dialysis \& } \\
\text { transplant) and irbesartan }\end{array}$ & $\begin{array}{l}12.003 \text { years with 'early irbesartan', } \\
11.332 \text { years with 'late irbesartan', } \\
11.223 \text { years with control }(0.780 \text { years } \\
\text { gained for irbesartan vs control) }\end{array}$ & $\begin{array}{l}\text { 'Early irbesartan' vs. } \\
\text { control: }-\$ 7,603 \text {, 'late } \\
\text { irbesartan' vs. control: } \\
-\$ 3,233[2004]\end{array}$ & & $\begin{array}{l}\text { Cost saving [early } \\
\text { irbesartan] }\end{array}$ \\
\hline $\begin{array}{l}\text { Annemans L } \\
\text { et al., } 2008 \text { China, } \\
\text { Taiwan, Malaysia, } \\
\text { Thailand, South } \\
\text { Korea [60] }\end{array}$ & 5 & 5 & $\begin{array}{l}\text { Third party } \\
\text { payer }\end{array}$ & $\begin{array}{l}\text { The cost of ESRD (dialysis \& } \\
\text { transplant) and irbesartan }\end{array}$ & $\begin{array}{l}\text { 'Early irbesartan' strategy had the longest } \\
\text { life expectancy (no detail data) }\end{array}$ & $\begin{array}{l}\text { The least expensive } \\
\text { strategy: 'early } \\
\text { irbesartan' (no detail } \\
\text { data) }\end{array}$ & & $\begin{array}{l}\text { Cost saving [early } \\
\text { irbesartan] }\end{array}$ \\
\hline \multicolumn{9}{|l|}{ Valsartan } \\
\hline $\begin{array}{l}\text { Smith DG et al., } \\
2004 \text { US [61] }\end{array}$ & 3 & 3 & $\begin{array}{l}\text { Third-party } \\
\text { payer }\end{array}$ & $\begin{array}{l}\text { Medical care costs including } \\
\text { costs of study drugs, routine } \\
\text { health care services, and } \\
\text { aggregate estimates of medical } \\
\text { care associated with the } \\
\text { various health states. }\end{array}$ & $\begin{array}{l}6.390 \text { QALYs with valsartan, } 5.835 \text { QALYs } \\
\text { with amlodipine ( } 0.555 \text { QALYs gained for } \\
\text { valsartan) }\end{array}$ & $-\$ 32,412$ [2001] & $-€ 30,424$ & $\begin{array}{l}\text { Cost saving } \\
\text { [valsartan] }\end{array}$ \\
\hline
\end{tabular}

a: In which year the value of money standardized was not clear. It was assumed to be one year before the publication

b: The total discount rate within time horizon, not annually. 
screening for albuminuria with ACEIs treatment was approximately $€ 16,700 /$ LYG (2006 value) for subjects with a urinary albumin excretion $>15 \mathrm{mg} / \mathrm{d}$ compared with no screening when adopting the Dutch health care perspective. This was in accordance with the analyses from Boersma $C$ et al. [72] suggesting the potentially favorable cost-effectiveness of population-based screening for MiA compared with other alternatives. Notably, however the latter two articles were for prevention of cardiovascular and renal events in the general population, not particularly for diabetic patients.

\section{Cost-effectiveness of ARBs}

The pharmacoeconomic results of ARBs for renal disease in patients with type 2 diabetes were reviewed previously. Ravera et al. [22] and Boersma et al. [21] reviewed the economic evaluations for ARBs and concluded that evaluations derived from RENAAL, IDNT, IRMA-2 and MARVAL all suggested ARBs to be cost saving compared with conventional therapy in type 2 diabetes patients with nephropathy. Postma \& de Zeeuw [26] reviewed the economic benefits of preventing ESRD in patients with type 2 diabetes. They divided the RAAS drug treatment into early and late interventions and concluded that early intervention strategies appear more effective in reducing the risk and the pharmacoeconomic profiles of early intervention clearly outweigh those of late intervention.

From our literature search, there were various economic evaluations on the ARBs losartan, irbesartan and valsartan. There were little differences between studies in each subgroups of ARBs concerning the analysis model, time horizon and measurement of costs and benefits. Although the results varied in different studies and countries, all conclusions supported ARBs as a costsaving choice.

\section{Differences in economic evaluations of ACEls and ARBs}

The trials referred to in the studies included in this review had different patient characteristics and treatment strategies. Patients enrolled in ACEIs trials were mainly normotensive, while patients enrolled in ARBs trials were mainly hypertensive. Trails with ACEIs had no equal BP control in placebo groups, whereas trials with ARBs had active BP control in placebo groups. Differences in time horizons used for ACEIs and ARBs present another reason hindering comparison of cost effectiveness between these two drug classes.

Referring to the analytic models, the transition probabilities between two states in the Markov model adopted in these ACEIs studies were from different trials, which may weaken the internal validity of the simulation model used and effectiveness results generated. The analytic models used for ARBs were relatively consistent in their strong alignment to the clinical trials available. Similar methods were adjusted to different country settings. This enhanced similarity in cost-effectiveness results of the same ARB drug in different countries. One might argue that the majority of economic evaluations for losartan were cost analyses with existing trial-based effectiveness as the building block.

\section{Differences in evaluation results of ACEls and ARBs}

Previous reviews [18-26] of ACEIs and ARBs didn't summarize the differences between ACEIs and ARBs in the absence of direct comparisons between ARBs and ACE inhibitors in terms of cost-effectiveness. In this review, also no valid comparison between ACEIs and ARBs is possible regarding cost-effectiveness.

In the lifetime treatment for diabetic nephropathy, cost of dialysis when patients develop to ESRD plays an important role in the burden of disease. Comparing to the cost of ESRD, the cost of drugs comprise a relatively low proportion in the total disease expenditure. As ACEIs and ARBs both can delay the deterioration of kidney function to save huge cost due to treatment, results of the economic evaluations included in this review are all pointing into the same direction that these two drug classes are cost-saving or very cost-effective. Furthermore, most ARBs now are available in generic forms and thus cheaper than when these evaluations were performed, which makes ARBs and ACEIs more similar in both effectiveness and cost. Therefore, similar cost-effectiveness result between ACEIs and ARBs can be hypothesized and results in this review strengthen the relevance of the choice made in guidelines $[14,18]$ of recommending ACEIs or ARBs as both presenting cost-effective choices for patients with diabetic nephropathy.

\section{Limitations}

In our review, although the standardized results showed an overview of the cost-effectiveness results of ACEIs and ARBs, to calculate a synthesized economic evaluation result of ACEIs and ARBs using the cost-effectiveness results in different economic evaluations could not validly be done, given all the aforementioned differences. This is mainly due to two limitations. Firstly, the baseline characteristics of the populations varied in the studies included. Secondly, the effectiveness outcomes varied in different studies.

Various selected studies in this review were strongly based on clinical trial settings. Trials are the gold standard for internal validity, but the problem is the lack of external validity [73]. The challenges and the need to include the real-world evidence in economic evaluations has been pointed out by pharmacoeconomic researchers [74]. In the mentioned cost-effectiveness analysis of screening for MiA by Boersma $\mathrm{C}$ et al. [72], they used population-based observational data, rather than efficacy data from clinical 
trials. The obvious problem is these settings is how to adjust for potential confounders and this requires careful consideration. For example, the extent in which data cover the population actually using the drugs, the adverse drug events and the drug use pattern all influence the results of effectiveness analysis. Findings from drug utilization studies relevant to aspects involving (non-)adherence or safety issues should be used in future analyses of drugs' (cost-)effectiveness. In our efforts to extract some safety information from our current included studies, only two articles $[37,38]$ mention a higher risk of dry cough associated with ACE inhibitors and discuss whether this side effect would influence the cost-effectiveness of ACEIs. This systematic review illustrates the lack of inclusion of observational data in the pharmacoeconomic evaluations so far performed.

\section{Conclusion}

Considering the current evidence, both ACEIs and ARBs are cost-saving compared with conventional therapy excluding a RAAS inhibitors. There is a lack of evidence in direct comparison of these two drug classes in consistent economic evaluations. Because of the limited external validity in using RCT data and the simulation results derived from trial-based analytical models, observational data should be used to confirm these trial-based costeffectiveness analyses' results.

\section{Additional file}

Additional file 1: Critical appraisal checklist for economic

evaluations.

\section{Competing interests}

YH works as a PhD student in University Medical Center Groningen (UMCG). Funding was received from University of Groningen. The results of this paper have not been presented or published elsewhere, in whole or in part.

\section{Authors' contributions}

$\mathrm{YH}$ and $\mathrm{QZ}$ performed the literature search, data collection and analysis and wrote the draft. $\mathrm{YH}, \mathrm{FH}$ and MP contributed to the study design, and reviewing the manuscript. All authors contributed to the conception and design, and read and approved the final manuscript.

\section{Acknowledgements \\ The authors are grateful to Professor Dr. Dick de Zeeuw (UMCG) for supporting the study design and Dr. Petra Denig (UMCG) for commenting on an earlier version of this manuscript.}

\section{Author details}

'Department of Pharmacy, Unit of Pharmaco Epidemiology \& Pharmaco Economics, University of Groningen, Groningen, The Netherlands. ${ }^{2}$ Department of Clinical Pharmacology, University Medical Center Groningen, University of Groningen, Groningen, The Netherlands. ${ }^{3}$ School of Public Health, Fudan University, Shanghai, China.

Received: 7 March 2013 Accepted: 6 January 2014

Published: 15 January 2014

\section{References}

1. Ritz E, Orth SR: Nephropathy in patients with type 2 diabetes mellitus. N Engl J Med 1999, 341(15):1127-1133.

2. New JP, Middleton RJ, Klebe B, Farmer CK, de Lusignan S, Stevens PE, O'Donoghue DJ: Assessing the prevalence, monitoring and management of chronic kidney disease in patients with diabetes compared with those without diabetes in general practice. Diabet Med 2007, 24(4):364-369.

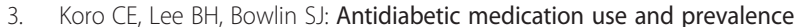
of chronic kidney disease among patients with type 2 diabetes mellitus in the United States. Clin Ther 2009, 31(11):2608-2617.

4. Bakris $\mathrm{GL}$ : Recognition, pathogenesis, and treatment of different stages of nephropathy in patients with type 2 diabetes mellitus. Mayo Clin Proc 2011, 86(5):444-456.

5. Gross JL, de Azevedo MJ, Silveiro SP, Canani LH, Caramori ML, Zelmanovitz T: Diabetic nephropathy: diagnosis, prevention, and treatment. Diabetes Care 2005, 28(1):164-176.

6. Scheffel RS, Bortolanza D, Weber CS, Costa LA, Canani LH, Santos KG, Crispim D, Roisenberg I, Lisbôa HR, Tres GS, Tschiedel B, Gross JL: Prevalence of micro and macroangiopatic chronic complications and their risk factors in the care of outpatients with type 2 diabetes mellitus. Rev Assoc Med Bras 2004, 50(3):263-267.

7. Ubink-Veltmaat LJ, Bilo HJ, Meyboom-de Jong B: Microalbuminuria in patients with type 2 diabetes mellitus in general practice. Ned Tijdschr Geneeskd 2004, 148(41):2026-2030.

8. Wu AY, Kong NC, de Leon FA, Pan CY, Tai TY, Yeung VT, Yoo SJ, Rouillon A, Weir MR: An alarmingly high prevalence of diabetic nephropathy in Asian type 2 diabetic patients: the MicroAlbuminuria Prevalence (MAP) Study. Diabetologia 2005, 48(1):17-26.

9. Palmer AJ, Valentine WJ, Chen R, Mehin N, Gabriel S, Bregman B, Rodby RA: A health economic analysis of screening and optimal treatment of nephropathy in patients with type 2 diabetes and hypertension in the USA. Nephrol Dial Transplant 2008, 23(4):1216-1223.

10. Lea JP, Nicholas SB: Diabetes mellitus and hypertension: Key risk factors for kidney disease. J Natl Med Assoc 2002, 94(Suppl 8):s7-s15.

11. U.S. Renal Data System: USRDS 2011 Annual Data Report: Atlas of end-stage renal disease in the United States. Bethesda, MD: National Institutes of Health National Institute of Diabetes and Digestive and Kidney Diseases; 2011.

12. Couser WG, Remuzzi G, Mendis S, Tonelli M: The contribution of chronic kidney disease to the global burden of major noncommunicable diseases. Kidney Int 2011, 80(12):1258-1270.

13. Rippin JD, Barnett AH, Bain SC: Cost-effective strategies in the prevention of diabetic nephropathy. Pharmacoeconomics 2004, 22(1):9-28.

14. American Diabetes Association: Standards of medical care in diabetes. Diabetes Care 2005, 28(Suppl 1):s4-s36.

15. Matchar DB, McCrory DC, Orlando LA, Patel MR, Patel UD, Patwardhan MB, Powers B, Samsa GP, Gray RN: Systematic review: comparative effectiveness of angiotensin-converting enzyme inhibitors and angiotensin II receptor blockers for treating essential hypertension. Ann Intern Med 2008, 148(1):16-29.

16. Pylypchuk GB: ACE-inhibitor versus angiotensin II blocker induced cough and angioedema. Ann Pharmacother 1998, 32(10):1060-1066.

17. Fuchs SA, Meyboom RH, van Puijenbroek EP, Guchelaar HJ: Use of angiotensin receptor antagonists in patients with ACE inhibitor induced angioedema. Pharm World Sci 2004, 26(4):191-192.

18. Chadban S, Howell M, Twigg S, Thomas M, Jerums G, Cass A, Campbell D, Nicholls K, Tong A, Mangos G, Stack A, Maclsaac RJ, Girgis S, Colagiuri R, Colagiuri S, Craig J, CARI: The CARI guidelines. Cost-effectiveness and socioeconomic implications of prevention and management of chronic kidney disease in type 2 diabetes. Nephrology (Carlton) 2010, 15(Suppl 1):s195-s203.

19. Carides GW: Losartan: a pharmacoeconomic review. JME 2007, 10(4):573-585

20. Bramlage $P$, Schindler $C$ : Differences in pharmacology and their translation into differences in clinical efficacy-a comparison of the renin angiotensin blocking agents irbesartan and losartan. Expert Opin Pharmacother 2010, 11(4):521-535.

21. Boersma C, Atthobari J, Gansevoort RT, den De Jong-Van Berg LT, De Jong PE, De Zeeuw D, Annemans LJ, Postma MJ: Pharmacoeconomics of angiotensin II antagonists in type 2 diabetic patients with nephropathy: implications for decision making. Pharmacoeconomics 2006, 24(6):523-535. 
22. Ravera M, Re M, Vettoretti S: Economic evaluation of angiotensin receptor blockers in type 2 diabetes, hypertension, and nephropathy. J Am SoC Nephrol 2006, 17(4 Suppl 2):s44-s48.

23. Palmer AJ, Tucker DM, Valentine WJ, Roze S, Gabriel S, Cordonnier DJ: Costeffectiveness of irbesartan in diabetic nephropathy: a systematic review of published studies. Nephrol Dial Transplant 2005, 20(6):1103-1109.

24. Palmer AJ, Rodby RA: Health economics studies assessing irbesartan use in patients with hypertension, type 2 diabetes, and microalbuminuria. Kidney Int Supp/ 2004, 92:s118-s120.

25. Postma MJ, Kruidhof H, den De Jong-van Berg LT, De Zeeuw D: Pharmacoeconomic aspects of losartan treatment to delay progression of renal disease in patients with Type 2 diabetes. Expert Opin Pharmacother 2003, 4(9):1543-1550.

26. Postma MJ, de Zeeuw D: The economic benefits of preventing end-stage renal disease in patients with type 2 diabetes mellitus. Nephrol Dial Transplant 2009, 24(10):2975-2983.

27. Drummond MF, Sculpher MJ, Torrance GW, O'Brien BJ, Stoddart GL: Chapter 3: critical assessment of economic evaluation. In Methods for the Economic Evaluation of Health Care Programmes. 3rd edition. New York: Oxford University Press; 2005:27-53.

28. Inflation, GDP deflator (annual\%). http://data.worldbank.org/indicator/NY GDP.DEFL.KD.ZG

29. Currency and foreign exchange. http://www.xe.com.

30. Grosse SD: Assessing cost-effectiveness in health care: history of the $\$ 50,000$ per QALY threshold. Value Health 2008, 8(2):165-178

31. Li R, Zhang P, Barker LE, Chowdhury FM, Zhang X: Cost-effectiveness of interventions to prevent and control diabetes mellitus: a systematic review. Diabetes Care 2010, 33(8):1872-1894.

32. Seng WK, Hwang SJ, Han DC, Teong CC, Chan J, Burke TA, Carides GW, Choi YJ: Losartan reduces the costs of diabetic end-stage renal disease: an Asian perspective. Nephrology (Carlton) 2005, 10(5):520-524.

33. Golan L, Birkmeyer JD, Welch HG: The cost-effectiveness of treating all patients with type 2 diabetes with angiotensin-converting enzyme inhibitors. Ann Intern Med 1999, 131(9):660-667.

34. Sakthong P, Tangphao O, Eiam-Ong S, Kamolratanakul P, Supakankunti S, Himathongkam T, Yathavong K: Cost-effectiveness of using angiotensinconverting enzyme inhibitors to slow nephropathy in normotensive patients with diabetes type II and microalbuminuria. Nephrology 2001, 6(2):71-77.

35. Rosen AB, Hamel MB, Weinstein MC, Cutler DM, Fendrick AM, Vijan S: Costeffectiveness of full medicare coverage of angiotensin-converting enzyme inhibitors for beneficiaries with diabetes. Ann Intern Med 2005, 143(2):89-99.

36. Campbell HM, Boardman KD, Dodd MA, Raisch DW: Pharmacoeconomic analysis of angiotensin-converting enzyme inhibitors in type 2 diabetes: a Markov model. Ann Pharmacother 2007, 41(7):1101-1110.

37. Adarkwah CC, Gandjour A: Cost-effectiveness of angiotensin-converting enzyme inhibitors and angiotensin II receptor blockers in newly diagnosed type 2 diabetes in Germany. Int J Technol Assess Health Care 2010, 26(1):62-70.

38. Adarkwah CC, Gandjour A, Akkerman M, Evers SM: Cost-effectiveness of angiotensin-converting enzyme inhibitors for the prevention of diabetic nephropathy in The Netherlands-a Markov model. PLoS One 2011, 6(10):e26139.

39. Herman WH, Shahinfar S, Carides GW, Dasbach EJ, Gerth WC, Alexander CM, Cook JR, Keane WF, Brenner BM: Losartan reduces the costs associated with diabetic end-stage renal disease: the RENAAL study economic evaluation. Diabetes Care 2003, 26(3):683-687.

40. Souchet T, Durand Zaleski I, Hannedouche T, Rodier M, Gaugris S, Passa P, RENAAL study: An economic evaluation of Losartan therapy in type 2 diabetic patients with nephropathy: an analysis of the RENAAL study adapted to France. Diabetes Metab 2003, 29(1):29-35.

41. Burgess ED, Carides GW, Gerth WC, Marentette MA, Chabot I, Canadian Hypertension Society: Losartan reduces the costs associated with nephropathy and end-stage renal disease from type 2 diabetes: economic evaluation of the RENAAL study from a Canadian perspective. Can J Cardiol 2004, 20(6):613-618.

42. Szucs TD, Sandoz MS, Keusch GW: The cost-effectiveness of losartan in type 2 diabetics with nephropathy in Switzerland-an analysis of the RENAAL study. Swiss Med Wkly 2004, 134(31-32):440-447.

43. Arredondo A, Burke TA, Carides GW, Lemus E, Querol J: The impact of losartan on the lifetime incidence of ESRD and costs in Mexico. Rev Invest Clin 2005, 57(3):399-405.
44. Vora J, Carides G, Robinson P: Effects of Losartan-based therapy on the incidence of end-stage renal disease and associated costs in type 2 diabetes mellitus: a retrospective cost -effectiveness analysis in the United Kingdom. Curr Ther Res Clin E 2005, 66(6):475-485.

45. Carides GW, Shahinfar S, Dasbach EJ, Keane WF, Gerth WC, Alexander CM, Herman WH, Brenner BM, RENAAL Investigators: The impact of losartan on the lifetime incidence of end-stage renal disease and costs in patients with type 2 diabetes and nephropathy. Pharmacoeconomics 2006, 24(6):549-558.

46. Stafylas PC, Sarafidis PA, Lasaridis AN, Tsakni E, Niakas DA, Dombros NV, Grekas DM, Bakris GL: Cost-effectiveness of losartan in diabetic nephropathy: a Greek perspective. J Nephrol 2007, 20(6):703-715

47. de Portu S, Citarella A, Cammarota S, Menditto E, Mantovani LG: Pharmacoeconomic consequences of losartan therapy in patients undergoing diabetic end stage renal disease in EU and USA. Clin Exp Hypertens 2011, 33(3):174-178.

48. Rodby RA, Chiou CF, Borenstein J, Smitten A, Sengupta N, Palmer AJ, Roze S, Annemans L, Simon TA, Chen RS, Lewis EJ, Collaborative Study Group: The cost-effectiveness of irbesartan in the treatment of hypertensive patients with type 2 diabetic nephropathy. Clin Ther 2003, 25(7):2102-2119.

49. Palmer AJ, Annemans L, Roze S, Lamotte M, Rodby RA, Cordonnier DJ: An economic evaluation of irbesartan in the treatment of patients with type 2 diabetes, hypertension and nephropathy: cost-effectiveness of Irbesartan in Diabetic Nephropathy Trial (IDNT) in the Belgian and French settings. Nephrol Dial Transplant 2003, 18(10):2059-2066.

50. Coyle D, Rodby RA: Economic evaluation of the use of irbesartan and amlodipine in the treatment of diabetic nephropathy in patients with hypertension in Canada. Can J Cardiol 2004, 20(1):71-79.

51. Palmer AJ, Annemans L, Roze S, Lamotte M, Rodby RA, Bilous RW: An economic evaluation of the Irbesartan in Diabetic Nephropathy Trial (IDNT) in a UK setting. J Hum Hypertens 2004, 18(10):733-738.

52. Palmer AJ, Annemans L, Roze S, Lamotte M, Lapuerta P, Chen R, Gabriel S, Carita P, Rodby RA, de Zeeuw D, Parving HH: Cost-effectiveness of early irbesartan treatment versus control (standard antihypertensive medications excluding ACE inhibitors, other angiotensin-2 receptor antagonists, and dihydropyridine calcium channel blockers) or late irbesartan treatment in patients with type 2 diabetes, hypertension, and renal disease. Diabetes Care 2004, 27(8):1897-1903.

53. Palmer AJ, Annemans L, Roze S, Lapuerta P, Chen R, Gabriel S, Carita P, Rodby RA, de Zeeuw D, Parving HH, De Alvaro F: Irbesartan is projected to be cost and life saving in a Spanish setting for treatment of patients with type 2 diabetes, hypertension, and microalbuminuria. Kidney Int Supp/ 2005, 93:s52-s54.

54. Palmer AJ, Roze S, Valentine WJ, Ray JA, Frei A, Burnier M, Hess B, Spinas GA, Brändle $M$ : Health economic implications of irbesartan plus conventional antihypertensive medications versus conventional blood pressure control alone in patients with type 2 diabetes, hypertension, and renal disease in Switzerland. Swiss Med Wkly 2006, 136(21-22):346-352.

55. Palmer AJ, Valentine WJ, Tucker DM, Ray JA, Roze S, Annemans L, Lapuerta P, Chen R, Gabriel S, Carita P, Rodby RA, de Zeeuw D, Parving HH, Laville M: A French cost-consequence analysis of the renoprotective benefits of irbesartan in patients with type 2 diabetes and hypertension. Curr Med Res Opin 2006, 22(11):2095-2100.

56. Palmer AJ, Valentine WJ, Ray JA, Roze S, Muszbek N: Health economic implications of irbesartan treatment versus standard blood pressure control in patients with type 2 diabetes, hypertension and renal disease: a Hungarian analysis. Eur J Health Econ 2007, 8(2):161-168.

57. Palmer AJ, Valentine WJ, Ray JA: Irbesartan treatment of patients with type 2 diabetes, hypertension and renal disease: a UK health economics analysis. Int J Clin Pract 2007, 61(10):1626-1633.

58. Coyle D, Rodby R, Soroka S, Levin A, Muirhead N, de Cotret PR, Chen R, Palmer A: Cost-effectiveness of irbesartan 300 mg given early versus late in patients with hypertension and a history of type 2 diabetes and renal disease: a Canadian perspective. Clin Ther 2007, 29(7):1508-1523.

59. Yang WC, Hwang SJ, Annemans L, Ray JA, Roze S, Valentine WJ, Palmer AJ: Irbesartan and amlodipine in the treatment of patients with microalbuminuria, hypertension and type 2 diabetes in Taiwan: a modelling projection over 25 years. JME 2007, 10(4):539-552.

60. Annemans L, Demarteau N, Hu S, Lee TJ, Morad Z, Supaporn T, Yang WC, Palmer AJ: An Asian regional analysis of cost-effectiveness of early irbesartan treatment versus conventional antihypertensive, late amlodipine, and late irbesartan treatments in patients with type 2 diabetes, hypertension, and nephropathy. Value Health 2008, 11(3):354-364. 
61. Smith DG, Nguyen AB, Peak CN, Frech FH: Markov modeling analysis of health and economic outcomes of therapy with valsartan versus amlodipine in patients with type 2 diabetes and microalbuminuria. J Manag Care Pharm 2004, 10(1):26-32.

62. Brenner BM, Cooper ME, de Zeeuw D, Keane WF, Mitch WE, Parving HH, Remuzzi G, Snapinn SM, Zhang Z, Shahinfar S, RENAAL Study Investigators: Effects of losartan on renal and cardiovascular outcomes in patients with type 2 diabetes and nephropathy. N Engl J Med 2001, 345(12):861-869.

63. Lewis EJ, Hunsicker LG, Bain RP, Rohde RD: The effect of angiotensinconverting-enzyme inhibition on diabetic nephropathy. The Collaborative Study Group. N Engl J Med 1993, 329(20):1456-1462.

64. Ravid M, Savin H, Jutrin I, Bental T, Katz B, Lishner M: Long-term stabilizing effect of angiotensin-converting enzyme inhibition on plasma creatinine and on proteinuria in normotensive type II diabetic patients. Ann Intern Med 1993, 118(8):577-581.

65. Ravid M, Brosh D, Levi Z, Bar-Dayan Y, Ravid D, Rachmani R: Use of enalapril to attenuate decline in renal function in normotensive, normoalbuminuric patients with type 2 diabetes mellitus. A randomized, controlled trial. Ann Intern Med 1998, 128(12 Pt 1):982-988.

66. Ravid M, Lang R, Rachmani R, Lishner M: Long-term renoprotective effect of angiotensin-converting enzyme inhibition in non-insulin-dependent diabetes mellitus. A 7-year follow-up study. Arch Intern Med 1996, 156(3):286-289.

67. Effects of ramipril on cardiovascular and microvascular outcomes in people with diabetes mellitus: results of the HOPE study and MICROHOPE substudy. Heart Outcomes Prevention Evaluation Study Investigators. Lancet 2000, 355(9200):253-259.

68. Lewis EJ, Hunsicker LG, Clarke WR, Berl T, Pohl MA, Lewis JB, Ritz E, Atkins RC, Rohde R, Raz I, Collaborative Study Group: Renoprotective effect of the angiotensin-receptor antagonist irbesartan in patients with nephropathy due to type 2 diabetes. N Engl J Med 2001, 345(12):851-860.

69. Parving HH, Lehnert H, Bröchner-Mortensen J, Gomis R, Andersen S, Arner P, Irbesartan in Patients with Type 2 Diabetes and Microalbuminuria Study Group: The effect of irbesartan on the development of diabetic nephropathy in patients with type 2 diabetes. N Engl J Med 2001, 345(12):870-878

70. Viberti G, Wheeldon NM, MicroAlbuminuria Reduction With VALsartan (MARVAL) Study Investigators: Microalbuminuria reduction with valsartan in patients with type 2 diabetes mellitus: a blood pressure-independent effect. Circulation 2002, 106(6):672-678.

71. Atthobari J, Asselbergs FW, Boersma C, de Vries R, Hillege HL, van Gilst WH, Gansevoort RT, de Jong PE, den De Jong-van Berg LT, Postma MJ, PREVEND IT Study Group: Cost-effectiveness of screening for albuminuria with subsequent fosinopril treatment to prevent cardiovascular events: a pharmacoeconomic analysis linked to the prevention of renal and vascular endstage disease (PREVEND) study and the prevention of renal and vascular endstage disease intervention trial (PREVEND IT). Clin Ther 2006, 28(3):432-444.

72. Boersma C, Gansevoort RT, Pechlivanoglou P, Visser ST, van Toly FF, De Jong-Van Den Berg LT, de Jong PE, Postma MJ, Prevention of Renal and Vascular End Stage Disease Study Group: Screen-and-treat strategies for albuminuria to prevent cardiovascular and renal disease: costeffectiveness of nationwide and targeted interventions based on analysis of cohort data from the Netherlands. Clin Ther 2010, 32(6):1103-1121.

73. Drummond MF: Experimental versus observational data in the economic evaluation of pharmaceuticals. Med Decis Making 1998, 18(Suppl 2):s12-s18.

74. Baltussen R, Leidl R, Ament A: Real world designs in economic evaluation. Bridging the gap between clinical research and policy-making. Pharmacoeconomics 1999, 16(5 Pt 1):449-458.

doi:10.1186/1471-2369-15-15

Cite this article as: Huang et al.: Economic evaluations of angiotensinconverting enzyme inhibitors and angiotensin II receptor blockers in type 2 diabetic nephropathy: a systematic review. BMC Nephrology 2014 15:15.

\section{Submit your next manuscript to BioMed Central and take full advantage of:}

- Convenient online submission

- Thorough peer review

- No space constraints or color figure charges

- Immediate publication on acceptance

- Inclusion in PubMed, CAS, Scopus and Google Scholar

- Research which is freely available for redistribution

Submit your manuscript at www.biomedcentral.com/submit
C Biomed Central 